RECENT EVOLUTIONARY THEORIZING ABOUT ECONOMIC CHANGE

Richard R. Nelson

School of International and Public Affairs, Columbia University, New York, USA

RR-96-5

April 1996

Reprinted from the Journal of Economic Literature,

Vol. XXXIII(March 1995), pp. 48-90.

INTERNATIONAL INSTITUTE FOR APPLIED SYSTEMS ANALYSIS

Laxenburg, Austria 
Research Reports, which record research conducted at IIASA, are independently reviewed before publication. Views or opinions expressed herein do not necessarily represent those of the Institute, its National Member Organizations, or other organizations supporting the work.

Reprinted with permission from the Journal of Economic Literature, Vol. XXXIII(March 1995), pp. 48-90.

Copyright (C)1995 American Economic Association.

All rights reserved. No part of this publication may be reproduced or transmitted in any form or by any means, electronic or mechanical, including photocopy, recording, or any information storage or retrieval system, without permission in writing from the copyright holder.

Printed by Novographic, Vienna, Austria. 


\section{Foreword}

The development and applications of an evolutionary approach to a wide set of economic phenomena is one of the central objectives of the Technological and Economic Dynamics (TED) Project at IIASA.

This work by Professor Richard Nelson provides a broad overview of evolutionary thinking, and in particular, of evolutionary interpretations of socio-economic change. The work assesses the state-of-the-art in fields like technological change, innovation-driven growth, and cultural and institutional evolution. As such it is not only a major input into the theoretical and empirical research of TED, but is an important reference for all students of evolutionary change.

Giovanni Dosi

Leader

Technological and Economic Dynamics Project 


\title{
Recent Evolutionary Theorizing About Economic Change
}

\author{
By RICHARD R. NELSON \\ Columbia University
}

\begin{abstract}
An earlier version of this essay was commissioned by Neil Smelser and Richard Swedberg, for their new Handbook of Economic Sociology (1994). I want to thank them for inducing me to try such a broad survey, and to thank the Sloan Foundation whose grant to the Consortium on Competition and Cooperation made the work possible. Sidney Winter, Stanley Metcalfe, Geoffrey Hodgson, and Giovanni Dosi, my close partners in developing cvolutionary economic theory, gave helpful comments on an earlier draft. So did more than three score other scholars to whom I sent out a copy. I thank them all, and hold them blameless for the result.
\end{abstract}

\section{Introduction}

The Mecca of the economist lies in economic biology ... But biological conccptions are more complex than those of mechanics; $a$ volume on Foundations must therefore give a relatively large place to mechanical analogies, and frequent use is made of the term equilibrium which suggests something of a static analogy. (Alfred Marshall 1948, p. xiv)

7 His FaMOUS PASSAGE from Alfred 1 Marshall's Principles of Economics (it first appeared in the fifth edition which came out in 1907) nicely brings out two issues, which are as germane to economics today as they were when Marshall wrote. The first is the heavy reliance by economists in their formal theorizing on the notion of "equilibrium." The other is the appeal that "biological conceptions" have for many economists, particularly when their focus is on economic change.

Marshall clearly believed that our science should aim to understand economic change and not simply the forces molding and sustaining the current configuration of economic variables. His "mechanical analogies" and equilibrium concepts included those of Newtonian dynamics, as well as those associated with the balancing of forces on bodies at rest. Since the time of Marshall, and following his lead, economists have developed their own equlibrium concepts. While until recently they were mostly associated with analysis of situations presumed to be at rest, in recent years much of economic theorizing has been concerned with dynamics, and the equilibria, like those of Newtonian dynamics, are ones in which the variables under 
study change over time. But Marshall might observe that the equilibrium concept in these models still somehow has a static feel to it.

Few economists confuse the formal static or dynamic equilibrium theory with the reality. Most readily acknowledge that at least some economic situations need to be understood as involving significant elements of novelty, so that the actors should be regarded as searching for a best action, as contrasted with actually having found it. In their analysis of certain economic phenomena, for example technical advance, many economists recognize that frequent or continuing shocks, generated internally as well as externally, may make it hazardous to assume that the system ever will get to an equilibrium; thus the fixed or moving equilibrium in the theory must be understood as an "attractor" rather than a characteristic of where the system is.

However, until recently at least, there has been a resistance to building these complications into formal models. Partly the reason is a belief that to do so would make the models intractable, or at least complex and difficult to understand. This seems to have been Marshall's concern. But nowadays this predilection seems more than simply a matter of analytic tractability and convenience. When expressly doing or talking theory, unlike Marshall most contemporary economists seem to be drawn to equilibrium concepts as a matter of aesthetics. General equilibrium theories are seen as elegant, and theories that depart from these canons are seen as somewhat ad hoc.

It is interesting, therefore, that when economists are describing or explaining particular empirical subject matter in a context that does not demand that they write or talk theory explicitly, they often eschew equilibrium language, and reveal the same inclination as did Marshall to make use of "biological conceptions" or metaphors. I noted above the proclivity of many economists to consider individuals and organizations as entities that search and "learn." Industrial organization economists sometimes characterize certain industries as "young" and others as "mature" with the connotation that various things naturally happen as an industry gets older (see e.g., Dennis Mueller and John Tilton 1969). Similar language often is used in comparing economies. Evolutionary or developmental language is used quite widely by economists to describe how the structure of an economy, or an industry, or technology, or the law, changes over time. Writings in economic history almost invariably are full of such biological metaphors.

All this is reminiscent of Marshall. Yet while he was attracted to "biological conceptions," it is apparent that Marshall never had in mind simply applying biological theory to economics. Indeed, the fact that he felt himself forced to fall back on "mechanical analogies" tells us that he found it very difficult to develop a formal theory, based on "biological conceptions," that he thought adequate for economic analysis.

In the years since Marshall, not many economists have even tried. (For a splendid history of evolutionary theorizing in economics, see Geoffrey Hodgson 1993.) Indeed, while some contemporary economists continue to feel the same tension as did Marshall, that group seems definitely a minority. One certainly can rationalize the two different styles of economic discourse and analysis as just what one would expect, given their purposes. Describing, and explaining, in a context where it is important to be sensitive to the details, is one thing. Theorizing is quite another.

However this proposition is problematic on at least two counts. First, the far- 
ther the language of particular explanation is from the logic of formal theory, the less analytic structure the latter can provide the former. Economists who would eschew equilibrium language, and use "biological conceptions" in describing and explaining, must pay an analytic price. Those who do implicitly are taking a position that the analytic structure of equilibrium theory misses elements they regard as essential to their story, and thus are willing to pay that price.

And second, the argument draws too sharp a line between formal theorizing and verbal economic explanation. Winter and I have argned that, because the real economic world is so complex, theorizing about it tends to proceed at at least two different levels of abstraction (Nelson and Winter 1982, pp. 46-48). Formal theorizing is one level. By formal theorizing we mean what economists do when they are self consciously putting forth a theoretical argument.

But economists also need to be understood as "theorizing" when they are trying to explain what lies behind the particular phenomena they are describing, even when they are not advertising their account as a "theory." Winter and I have called this kind of analysis "appreciative" theorizing. While starting with the empirical subject matter, the accounts put forth by economists of the development of an industry, or the evolution of a technology, focus on certain variables and ignore others, just as is the case with formal theory. Quite complex causal arguments often are presented as parts of these accounts, if generally in the form of stories.

Thus the difference between the language and the logic of economists' stories about economic growth, which often involve evolutionary or developmental concepts, and that of equilibrium theory, is described inappropriately as a difference between description and theory.
The difference is between two different kinds of theories, in the sense that the mechanisms and relationships treated as causal are different, or at least appear to be.

One could respond by arguing that, while the language may be different, in fact the substance of theories using "biological conceptions" and equilibrium theories is not very different. In particular, the theories predict much the same things. There is no real difference between saying that firms literally maximize, and saying that their behaviors have been learned through trial, error, and correction, and in some cases have been selected through the competitive process. Thus extant actors behave "as if" they maximize. (The classic statement of this position is, of course, Milton Friedman's, 1953.)

Economists are not alone in putting forth this argument. A number of evolutionary theorists in biology do also. Both the economists and the biologists who take this position admit that, at any particular time, the actual system may not be precisely in equilibrium, but propose that it generally is close enough so that the characteristics of equilibrium tell one a lot about the actual situation.

But economists who use the language of development and evolution in telling their stories apparently do not believe that concepts like optimization and equilibrium can explain adequately the phenomena they are addressing, and these economists have kindred souls in biology. Many students of biological evolution strongly deny the proposition that "optimization" provides a meaningful explanation for the character of extant living forms, even when the observed configuration seems relatively durable and stable (see e.g., Stephen Gould 1980). It has been argued that the process of evolution is strongly path dependent and there is no unique selection equilibrium. 
Any "optimizing" characteristics of what exists therefore must be understood as local and myopic, associated with the particular equilibrium that happens to obtain. The heart of any explanation of extant living forms thus must be evolutionary analysis of how the particular equilibrium, and not a different one, came to be. Further, often there is good reason to suspect that evolution presently is going on at a relatively rapid rate, and thus equilibrium of any kind is not an appropriate concept for analysis.

It would appear that many economists who use developmental and evolutionary language have in mind notions like these. While, as we shall see, the economists using evolutionary language in their theorizing are not of one ilk, almost all are, in effect, positing that to say that actors behave "as if" they were maximizing does not tell us much about why they are doing what they are, and provides only a start on any prediction of what they will end up doing if conditions change. Many clearly believe that path dependency is important in economics, and a number argue that the phenomena in which they are interested must be understood as associated with continuing disequilibrium, not equilibrium.

Until recently economists have used the language of evolution almost exclusively in their appreciative theorizing. However, in recent years evolutionary concepts have been employed increasingly in formal evolutionary theorizing. The book published by Sidney Winter and myself just over a decade ago (Nelson and Winter 1982) has been followed by a number of others also exploring formal evolutionary theorizing in economics. (See among others Dosi et al. 1988; Paolo Saviotti and Metcalfe 1991; Philip Anderson, Kenneth Arrow, and David Pines 1988; Richard Day and Gunnar Eliasson 1986; Norman Clark and Calestous Juma 1987; Lars Magnusson
1994.) Several recent articles have canvassed the new writing. (See for example Chris De Bresson 1987; and Richard Langlois and Michael Everett 1992.) Ulrich Witt (1992) has pulled together a collection of what he regards as classic articles in evolutionary theory. Hodgson (1993) has provided an elegant analytic history of evolutionary theorizing in economics, and a forceful argument that Marshall was right about Mecca. In 1991 a new Journal of Evolutionary Economics was founded, and several other new journals have advertised an interest in evolutionary economics.

The recent work on formal evolutionary economic theories has had several distinct, if connected, sources. One is the influence of developments in evolutionary theory in biology, and sociobiology, and the attempts to extend these lines of analysis to explain the evolution of human patterns of cooperation, coordination, and social behavior more generally. While originally an intellectual field dominated by scholars outside of economics, a number of economists have come to be attracted both by the questions, and some of the analytic ideas. (See e.g., Jack Hirshleifer and Juan Carlos Martinez-Coll 1988.)

My review will describe these developments. However, I will argue that the ideas developed to date in evolutionary sociobiology are not adequate to deal with the questions of most interest to economists concerned with long run economic change, for example the evolution of technologies and institutions.

The development of evolutionary game theory has drawn extensively on these ideas, but probably should be regarded as a field in its own right, with its own questions, and methods (H. Peyton Young 1993; Michihiro Kandori, George Mailath, and Rafael Rob 1993; Daniel Friedman 1991). The focus is on repeated games, and the problem of multi- 
ple Nash equilibria that is characteristic of such. The analytic tack that unifies a quite diverse body of writing is to specify an "evolutionary" process that is operative on the set of employed strategies, and to explore whether or not extant strategies converge to a steady state and, if so, the characteristics of such an equilibrium.

My review here will be concerned mostly with evolutionary analysis of long run and continuing economic change, and thus will deal only very selectively with evolutionary game theory. However, the notion that there may be multiple equilibria, and that an understanding of which one, if any, will be achieved may require an analysis of "out of equilibrium" behavior (i.e., that equilibrium is "path dependent") is very germane to the review presented here.

Recent developments in understanding of the mathematics of nonlinear dynamic systems, and recognition that many physical systems display properties that such dynamic models can explain and illuminate, is yet another stimulus to evolutionary theorizing in economics (Ilya Prigogene and Isabelle Stengers 1984; David Lane 1993). While some of this new analytic understanding has been employed in evolutionary game theory, and indeed evolutionary game theory might be considered a special case of models of complex dynamic systems, two features of the more general formulation are relevant here. First, for the most part (there are exceptions) evolutionary game theory continues an older tradition in game theory of thinking of a given finite set of (basic) strategies, with equilibrium being defined in terms of these or mixes of these. In contrast, in the more general formulation an equilibrium, if there is any such, is seen as emerging out of the dynamic process, and often involves patterns of behavior and activities that were absent early in the process. The number and nature of possible equilibria thus often cannot be specified ex ante. Second, while concerned with certain regularity properties in the time series, writers who identify their work as analysis of complex dynamic systems seem quite ready to believe that the system always will be "out of equilibrium."

Much of the work on complex dynamic systems is carried out through computer simulation. The tremendous increase in the power of computers, and the recent availability of programming languages and techniques that greatly facilitate simulation of complex dynamic systems, however, should be regarded as a factor in its own right that has stimulated the development of formal evolutionary theorizing in economics. To recall the quote from Marshall that began this essay, the complexity of "biological conceptions," in particular evolutionary processes, no longer poses the same analytic obstacles as was the case in the time of Marshall-or even twenty years ago.

Earlier I suggested that the appeal of equilibrium formal theorizing in economics was much more than a matter of computational feasibility, but reflected as well notions of aesthetics and elegance. But elegance is in the eye of the beholder. Those working with the new models of dynamic complex systems clearly are developing a sense of aesthetics of their own. And appreciation of a different kind of elegance seems to be spreading among economists.

All of the developments above have contributed to the rise of a body of writing by economists and kindred scholars who are interested in understanding and explaining aspects or sources of long run economic change, and have developed quite explicit and self consciously evolutionary models for that purpose. These writings are the focus of this essay. I will be concerned with evolutionary theorizing that arises out of empirical research, 
as contrasted with studies that develop evolutionary models or arguments because they are interesting in their own right, and which bring in empirical cases mainly as examples. Much, if not all, of this evolutionary theorizing has been developed by the authors because they have felt that "mechanical analogies" simply would not do for their task, and that "biological conceptions" were more illuminating. And in contrast with most earlier writing, these writers have made their evolutionary theorizing explicit.

Like Marshall, most of these writers, while drawn to biological conceptions or metaphors, have resisted simply transferring evolutionary concepts used in biology to their area of inquiry, but rather have tried to analyze the evolutionary dynamics at work there in its own right. This has not always proved easy. In many cases the processes involved appear to be, when they are looked at closely, quite complex. Also, there still is little experience that can be drawn upon in constructing an evolutionary theory germane to economic change. The studies I will review here are highly varied reflecting not only their different subject matter, but also the authors' particular ways of formulating an "evolutionary" theory. All of the theories considered here are formal theories, in that they have been explicitly put forth by their authors as a theory to explain particular phenomena. Some are expressed mathematically; some in words. The distinction that Winter and I made between formal and appreciative theorizing did not hinge on the media of exposition, although almost invariably theory expressed mathematically is formal theory in our terms. In our terms the hallmark of a formal theory is the explicit setting out of a causal account, however expressed. A highly relevant question, of course, is the logical coherence of the theoretical statement. Here, the use of mathematics would seem to help, but the history of economic thought displays many coherent verbal theories, and some incoherent mathematical ones.

The remainder of this article is organized as follows. In the following section I draw out the similarities, and differences, between the evolutionary economic theories I will be examining, and evolutionary theory in biology and sociobiology.

I turn next to the evolutionary theories that are the focus of this essay. Section III is concerned with a group of evolutionary theories about particular phenomena associated with long run economic change: science, technology, business organization, and law. Sections IV and $V$ deal with evolutionary theories that treat clusters of coevolving variables, the former with models of economic growth driven by technical advance, the latter with the coevolution of technology and industry structure. Sections VI and VII are concerned with organizations and institutions.

In the concluding section I reflect on the present state of evolutionary theorizing in economics. I also will attempt to sharpen the discussion of the ways in which evolutionary theorizing is different from neoclassical theorizing, and to propose some criteria that might enable one to evaluate the strengths and weaknesses of the alternatives. Some economists would argue that that issue ought to hinge on the quality of the predictions, but I will suggest that the issue is too complex for that.

\section{What Are the Characteristics of an Evolutionary Theory?}

What are the characteristics of an "evolutionary theory" of economic change, as contrasted with theories of economic change that employ "mechanical analogies"? In what ways are eco- 
nomic evolutionary theories similar to evolutionary theories in biology and sociobiology, and in what ways different? These are the questions addressed in this section.

\section{A. Evolutionary Theory as a General Theory}

One way to define evolutionary theory in general would be to start from biology, where evolutionary theory is best worked out, and explore where one can find close analogies to the variables and concepts of that theory in other areas of inquiry -in this case economics. However I believe that following this route would tie the discussion much too closely to biology. After all, as Hodgson (1993) has discussed at some length, the term "evolution" was in wide use long before it took on meaning as the name of a particular theory in biology.

I believe that much of the appeal of evolutionary language in economics is connected with the broader use of the term, as contrasted with its specific use in biology. Further, to start with biology risks getting stuck in notions that, while salient in biological evolution, seem irrelevant or wrong-headed when applied to economics. It seems more fruitful to start with a general notion of evolution, and then examine applications in specific areas-like biology or economics-as special cases.

The general concept of evolutionary theory that I propose, and employ in this essay, involves the following elements. The focus of attention is on a variable or set of them that is changing over time and the theoretical quest is for an understanding of the dynamic process behind the observed change; a special case would be a quest for understanding of the current state of a variable or a system in terms of how it got there. The theory proposes that the variable or system in question is subject to somewhat random variation or perturbation, and also that there are mechanisms that systematically winnow on that variation. Much of the predictive or explanatory power of that theory rests with its specification of the systematic selection forces. It is presumed that there are strong inertial tendencies preserving what has survived the selection process. However, in many cases there are also forces that continue to introduce new variety, which is further grist for the selection mill.

All of the evolutionary theories of economic change I will discuss have these characteristics. They also are central, of course, in evolutionary theory in biology. However, biology makes heavy use of other concepts that, by and large, are not used in in economics. The fact that sexuality and mating play a major role in the evolution of many species is important in biology but seldom used in economics. The concept of generations is used in biology, but does not apply easily to analyses of the evolution of technologies, firms, or institutions.

On the other hand, in some of the theories considered here the new "variety" that is created as grist for winnowing is systematically oriented toward new departures that seem appropriate to the context. That is, there is a directionally adaptive aspect to the innovation process. Also, what entities "learn" in such processes may, in some models, be passed on to other entities. That is, some of the economic evolutionary theories are Lamarkian, a version of evolutionary theory that has been discredited in biology. Some emphasize group selection. Other aspects that distinguish economic models from biological ones will be developed along the way.

In any case, the proposed general definition of an evolutionary process certainly rules out certain theories of change, for example those that are 
wholly deterministic. Thus under this definition, as apparently under Marshall's conception, Kepler's laws of planetary motion, together with Newton's gravitational theory that explains them, would not define an evolutionary theory. Nor would the standard neoclassical theory of economic growth, which basically presumes a moving general equilibrium, be regarded as an evolutionary theory. Neither would the execution of a detailed plan for the construction of a building, or any realization of a pre-specified blueprint, be considered an evolutionary process.

On the other hand the definition I am proposing also rules out theories of change where all the action is "random," as certain models in economics that purport that within an industry the growth or decline of particular firms is a random variable, possibly related to the size of the firm at any time, but otherwise not analyzable (see e.g., Herbert Simon and Charles Bonini 1958). One can trace through the random processes built into such models and predict the distribution of firm sizes at any time, for example that under certain specifications it will asymtotically become log normal. But under the definition presented here, these models would not be considered evolutionary models of economic change.

But revise the building construction story as follows. Assume that the original house design is a tentative one, because the builder is not exactly sure how to achieve what he or she wants, and thus the plan initially contains certain elements without any firm commitment to them, indeed that are there partly by chance. As the building gets constructed the builder gets a better idea of what the present plans imply, and where the original design is inadequate, and, where construction in place permits, revises the plan and the path of construction accordingly. Revise the firm growth model as follows. Assume that the firms differ in certain identifiable characteristics, and growth of those with certain ones turns out to be systematically greater than those that lack these. The industry gradually develops a structure in which only firms with these characteristics survive.

Both models now contain both random and systematic elements. Further, in both the systematic ones act by winnowing on the random ones. In the house design case, design elements turn out to please or displease the builder, and are accepted or rejected accordingly. In the industry evolution case, the "market" or something is selecting on firms that have certain attributes. A limitation of both stories is that neither is explicit about what it is that seems to give advantage. But both give hope that the analyst might be able to find out. Perhaps it is "cost per square foot" or "nicely shaped spaces" or some combination that explains why the builder revises the design as the information comes in. Perhaps it is production costs or ability to innovate that is determining whether firms thrive or fail. Of course the theory has limited explanatory power until the question of selection criteria gets answered. But if that question is answered adequately, the theory can explain, and to some extent predict.

The analytic structure of these two examples is reminiscent of that of evolutionary theory in biology, without being clones of it. The latter, however, seems closer to theory in biology because it refers to an actual population of things, while the former does not appear to, at least at first glance. In biology the use of the term evolutionary nowadays is firmly associated with analysis of actual populations of things. An embryo, or more generally a living creature, usually is described as developing, not evolving. In part this use of language reflects a predi- 
lection discussed earlier-that change "according to a plan" is usually not regarded as evolutionary. However, it is recognized widely that many random occurrences will affect the development of an embryo or a tree. The prejudice against using the term "evolutionary" to describe such biological processes stems from the fact that the term has been preempted for use in describing another class of biological phenomena. However, is it clear that prejudice should carry over outside of biology?

Consider our house builder, or an individual learning to play chess, or a firm trying to find a strategy for survival in a competitive industry. Our house builder can be regarded as having a number of plan variants, or perhaps as having one initially in mind but being aware that there are a set of possible changes that might turn out to be desirable. One can similarly regard the learning chess player or the firm. If firms, persons learning to play chess, or housebuilders, learn from experience and winnow or adapt their plans or strategies or behaviors, is it unreasonable to think of these as evolving? In reflecting on this, one might recognize that the learning, or adaptation, can be modeled in terms of a change in the probability distribution of possible actions that entity might take at any time, coming about as a result of feedback from what has been tried, and the consequences. These "learning" equations have basically the same form as the equations that describe the evolution of populations. (See e.g., John Holland et al. 1986.)

There is no great value in extended intellectual haggling about the precise boundaries which demarcate models of change that can be called evolutionary from those that should not be. As indicated, I choose to use the term "evolutionary" to define a class of theories, or models, or arguments, that have the fol- lowing characteristics. First, their purpose is to explain the movement of something over time, or to explain why that something is what it is at a moment in time in terms of how it got there; that is, the analysis is expressly dynamic. Second, the explanation involves both random elements which generate or renew some variation in the variables in question, and mechanisms that systematically winnow on extant variation. Third, there are inertial forces that provide continuity of what survives the winnowing.

The variation in the theory can be associated with an actual variety which exists at any time-as a distribution of genotypes or phenotypes, or firm policies. Alternately, it may characterize a set of potential values of a variable, only one of which is manifest at any time. Thus I would include theories of individual, organizational, or cultural learning and adaptation under my umbrella, if they fit other characteristics. Indeed, as we shall see, a characteristic of many of the economic evolutionary theories we will examine is that individual learning, organizational adaptation, and environmental selection of organizations, all are going on at the same time.

\section{B. Evolutionary Theory in Biology}

As is the case with any active scientific field, there is far from full agreement on all matters among modern biologists, ethnologists, paleontologists, and other scientists concerned with biological evolution. However, the following sketch captures that part of the generally agreed upon core that is most useful to lay out for our purposes in this essay, as well as some of the relevant bones of contention. (The following draws from many sources, but especially Richard Lewontin 1974; Elliott Sober 1984; David Hull 1988; and Ernst Mayr 1988.)

The theory is concerned with two actual populations as contrasted with po- 
tential ones. One is the population of genotypes, defined as the genetic inheritance of living creatures. The second is the population of phenotypes, defined in terms of a set of variables that happen to be of interest to the analyst, but which include those that influence the "fitness" of each living creature. These might include physical aspects like size, or sight, behavioral patterns like song, or responses to particular contingencies like something that can be eaten and is within reach, or a potential mate, or a member of one's own "group" soliciting help.

Phenotypic characteristics are presumed to be influenced by genotypic ones, but not uniquely determined by them. Modern evolutionary theory recognizes that the development of a living creature from its origins to its phenotypic characteristics at any time can be influenced by the environment through which it passes-whether there was adequate food supply when it was young or not, or the fact that it lost an eye in an accident. Modern evolutionary theory also recognizes a variety of learning experiences which shape the behavior of a phenotype, including how it was taught by its mother, whether particular behaviors early in life were rewarded, etc. However, if we hold off for a moment considering evolutionary theory that recognizes "culture" as something that can be transferred across generations, the hallmark of standard biological evolutionary theory is that only the genes, not any acquired characteristics or behavior, get passed on across the generations.

The notion of "generations" is basic to biological evolutionary theory. The phenotypes get born, live, reproduce (at least some of them do), and die (in most species ultimately all of them do). On the other hand, the genes get carried over to their offspring, who follow the same generational life cycle. Thus the genes provide the continuity of the evolutionary system, with the actual living creatures acting, from one point of view, as their transporters from generation to generation. For species that produce this way, sexuality provides a mechanism for combining genotypes in a manner that may create new ones. Mutations also create new genotypes. On the other hand selection winnows on the genetic variety through differential reproduction by (pairs of) phenotypes which augments the relative frequency of the genes of the more successful reproducers and diminishes that of the less.

In the generally held interpretation of this theory (there are other or more complex interpretations as well), selection operates directly on the phenotypes. It is they, not their genes per se, that are more or less fit. To repeat what was stressed above, phenotypes are not uniquely determined by genotypes. However the theory assumes a strong enough relationship between the two so that systematic selection on phenotypes results in systematic selection on genotypes.

There are several controversial, or at least open, aspects of this theory that are germane to our discussion here. For economists perhaps the most interesting question is whether, and if so in what sense, evolution can be understood to "optimize" fitness.

The optimization notion here clearly has roots in Herbert Spencer's notions (1887) of "survival of the fittest," and the implicit context is one in which competition among members of a population is sufficiently fierce that only the "fittest" survive. In recent years theorists have formalized this idea as a game for survival, and developed the concept of an "evolutionarily stable strategy" as the equilibrium solution to that game. (See e.g., Maynard Smith 1982.) The concept of "strategy" in these models is broad 
enough to encompass any phenotypic characteristic that matters for survival, and the strategies that survive in equilibrium are those that can best (at least small numbers of) other pre-specified strategies in the survival game.

In what sense is what survives optimal? The semantic correspondance between between survival and optimality seems most straightforward if the "game" is about different kinds of strategies passively competing for the same environmental "niche," and one type wins out. The winner might be understood as the most efficient forager, or something like that. However, things get somewhat more complicated if the game isn't simply about passive competition for a niche, but includes some strategies that involve attacking competitors of other sorts. then both efficient foraging and fighting prowess count in defining optimal, if that term is to be used to characterize what survives.

Even in such simple contexts, there are some subtleties that qualify the association of what "survives" with "optimal." For one thing, how a strategy fares in a series of plays of a game depends on the mix of strategies with which it competes. Thus what survives depends on what else is competing in the game. More, if the number of individuals associated with any particular strategy is finite, the very process of competition may eliminate along the path to an equilibrium strategies that would be in a stable equilibrium set as calculated ex ante. That is, the equilibrium may be strongly path dependent. (See e.g., Hirshleifer and Martinez-Coll 1988.)

Other complications come into view when one recognizes that "strategies" may have many aspects, and these may interact strongly in determining ability to compete and survive in a given environment. Thus being an effective predator requires a package of attributes, ability to get at the leaves on tall trees a different package. But then, whether a "gene" or an aspect of a strategy enhances survival or not may be strongly dependent upon the other genes or aspects of strategy. And a "mutation" that may be lethal in one species or strategy, may be helpful in another. Thus if strategies themselves evolve, they likely do so in a strongly path dependent way.

There may be important interactions across coexisting phenotypes-strategies. The existence of giraffes provides opportunites for large strong predators. But the number of the latter that can survive in equilibrium may depend on the number of the former, and vice versa. In turn the ecological equilibrium depends on the number of trees and the leaves that are available to giraffes. The emergence of an insect whose caterpillars feed on leaves of the tall trees may bring down the whole ecosystem.

Also, a number of students of biological evolution have argued that the selection environment almost never is constant (see e.g., Gould 1980, 1985). The insect population may get large, and then itself collapse after it has diminished the population of live trees. If the selection environment is not a constant, the phenotypes extant today may be strongly shaped by those that survived in a possibly very different environment some time ago (say giraffes that can eat the leaves of low bushes that the caterpillars do not like), and the offspring they had, as well as recent winnowing on the group extant yesterday. Again, the equilibrium is strongly path dependent, and today's "optimum" may be very local and likely poor stuff compared to what might have been.

Gould, among others, says he reads the evidence as indicating that the selection environment not only changes, but on many occasions is relatively lax. In a loose selection environment different 
phenotypes may grow in number more rapidly than others largely due to a combination of breeding capability and luck, rather than any special capabilities for "survival" in the environment in question. The same authors argue that the extinction of particular phenotypes usually is the result of catastrophes that happened to hit clusters of them, rather than the result of losing a competition with other phenotypes.

One also can ask what meaning there is to the optimality concept in a context in which mutation continues to go on, and some of the mutations enhance fitness, at least in prevailing environments. Modern evolutionary biology is not simply about selection pressures on extant phenotypes, but also about changes that appear from time to time in species, and also about the origins of new species. These latter phenomena would seem to require analysis of evolutionary processes that involve not only out-of-equilibrium behavior, but also the emergence of novelty. (See e.g., Walter Fontana and Leo Buss 1992; and Lane 1993.)

\section{Sociobiology}

As indicated, animal behavior has, for a long time, been a "phenotypic" characteristic of interest to evolutionary theorists. That behavior often involves, in an essential way, modes of interaction with fellow members of one's species. Over the last thirty years an important subdiscipline has grown up concerned with exactly these kinds of social behavior patterns. Much of this has been concerned with nonprimate animals-insect colonies, bird families and flocks, etc. A sizeable portion of it has, however, been concerned with humans. The part of the sociobiology literature concerned with nonhumans recognizes that learned behavior can be passed down from generation to generation, but in general has presumed, first, that the particular capa- bilities to learn and to transmit to offspring are tied to genes, and second, that the "learning" does not progress from generation to generation. To the extent that these behaviors enhance fitness, there is selection on the genes that facilitate them, according to the arguments sketched above. But learned behavior does not follow a cross generational path of its own.

The early work by Edward Wilson on the biological bases of human social behavior carried over basically this model. However, in subsequent writings by Charles Lumsden and Edward Wilson (1981), and by other scholars interested in extending evolutionary theory in biology so as to be able to treat human culture, prominently Luigi Cavalli-Sforza and Marcus Feldman (1981), Robert Boyd and Peter Richerson (1985), and William Durham (1991), human culture was recognized as something that could be modified, and improved, from generation to generation, and which had its own rules of transmission. These latter models all do presume a basic genetic biological capacity of humans for the development and transmission of culture. But beyond that these models treat the connections between the evolution of human behavior and culture, and genetic evolution, as something far more complex than that assumed in the models of insect and bird societies.

There are a number of important differences among these models. Thus Lumsden and Wilson, and Cavalli-Sforza and Feldman, tend to treat elements of culture as something that directly determine what people do and how effectively they do it, while Boyd and Richerson, and especially Durham, treat culture as prominently involving understandings and values that, like genes, influence behavior or capabilities, but do not directly determine these. Perhaps the most important difference among these models 
is the extent to which biology is seen as constraining and molding culture beyond the preconditions that all of these theories recognize. Put in the terms coined by Wilson, there are sharp disagreements regarding how long the "leash," and the extent to which evolution of culture itself has significantly extended the length of that "leash." Here Lumsden and Wilson are far closer to the animal sociobiology models than the other authors.

For the purposes of the discussion here, I want to focus on certain commonalities of the theories in this literature, which, I believe limit their range of applicability. In particular, all of them use as their examples relatively simple practices or artifacts or ideas or norms which can easily be thought of as being transmitted from person to person. Each tries to break down "culture" into small "gene like" subunits, which are assigned terms like meme, or culturgen. The simple technology-artifacts and beliefs employed as examples are a far distance from complex technologies like those associated with making semiconductors or aircraft, or scientific theories like that of biological evolution itself, or systems like patent law. While teachers and opinion leaders are admitted as "transmitters" or "influencers," there is nothing in these studies like universities, or scientific societies. Various forms of human organization are discussed, but there is no treatment of organizations like industrial R \& D laboratories, or business firms more generally, or elections or legislatures, or courts.

Most of the analyses clearly recognize that in principle an element of culture can spread for reasons that have little to do with enhancing individual biological fitness, in any straightforward manner, and some stress that as a general proposition. Boyd and Richerson even present a model example in which the profes- sional life of, say, a teacher, or a member of the clergy, is assumed to carry attractions of its own, but those who follow the calling actually have a smaller number of offspring than those who do not. Membership in the profession as a whole is sustained intergenerationally by new recruits. However, none of these analyses attempts to come to grips with the paths of cumulative evolution taken by cultural structures like science, technology, the law, standard forms of business organization, and the like, which clearly have been drawn and shaped by particular value systems, and particular mechanisms for inducing and winnowing change.

While important and interesting in its own right, the body of writing on cultural evolution that traces its origins to biological evolutionary theory, and then makes a sharp break, has not as yet tried to come to grips with the dynamics of change in modern industrial societies. To do so requires, it would seem, building into evolutionary analysis much more of the institutional complexity of modern societies than the literature above has hazarded thus far. Boyd and Richerson recognize this explicitly when they remark,

$$
\begin{aligned}
& \text { Understanding the institutional complexity of } \\
& \text { modern societies will require the mating of } \\
& \text { micro-level theory like the one we have de- } \\
& \text { veloped here with the more aggregated one } \\
& \text { of Nelson and Winter. (Boyd and Richerson } \\
& 1985, \text { p. 296) }
\end{aligned}
$$

This is just what the various studies we shall consider in the following sections have tried to do, if with varying levels of success.

\section{The Evolution of Particular Aspects of Culture}

There are three key differences between the evolutionary theories I consider here, and in the following sections, 
and those in sociobiology. First, there are no ties whatsoever between the cultural selection criteria and processes and biological fitness. Any coevolution in these theories is not between memes and genes, but between various elements of culture.

Second, the authors of the theories considered here are interested in explaining how and why a particular aspect of "culture" changed over time the way it did. Because their explanation is in terms of the workings of an evolutionary process, this forces them to identify some particular characteristic of merit and selection mechanisms enforcing it that favors certain variants over others, or which reinforces certain behaviors or inclinations and damps others. The theorists of biological and cultural coevolution discussed above have coined the term "cultural fitness," but seldom have got around to identifying it in particular cases where biological fitness is not an important variable at stake. Third, evolutionary theorists, coming from sociobiology, have by and large assumed selection mechanisms are individualistic, transmission mechanisms are person to person, and that "'memes" like genes are carried by individuals. Yet these perceptions seem quite inadequate for analysis of how science or modern technology evolves, or forms of business organization, or law.

This section will be concerned with evolutionary theories of just these elements of culture, all of them major and obviously intertwined aspects of the process of long run economic change. The theories discussed in this section largely repress the intertwining. Each theory deals with just one of these variables which is viewed as proceeding on its own, as it were. In the following two sections we shall consider theories in which interdependence and coevolution are recognized.
The collection of theories discussed in this section are all qualitative, and expressed verbally, as contrasted with being laid out mathematically. All are formal theories, in the sense of being put forth as self-conscious abstractions about what is driving the dynamics of the variables in question. However, none is developed mathematically. And some seem much better posed analytically than others, in that the logic seems tighter.

I also want to stress that each of the bodies of evolutionary theorizing discussed in this section is very large. My treatment of each, therefore, must be highly selective. My particular selection is designed not so much to be representative of the literatures involved, as to bring out some analytic issues about evolutionary theorizing.

\section{A. Science}

The proposition that science "evolves" has been around for some time, and there has been and continues to be a lively discussion about just how that evolutionary process works. For the most part the various theories put forth do satisfy my definition of what qualifies as an evolutionary theory. (For overviews see Henry Plotkin 1982; and David Hull 1988.)

Of recent writers in this vein, Donald Campbell $(1960,1974)$ probably is the most cited. Using Campbell's term, the development of new scientific hypotheses, or theories, is to some extent "blind," in that their originators cannot know for sure how they will fare when they are first put forth. Thus new scientific theories are like "mutations" in that some will succeed and be incorporated into the body of science, perhaps replacing older theories, or correcting them in some respects, or adding to them, and others will not succeed. Campbell relies largely on the ideas of Karl Popper (1968) for his "selection mechanism." 
Under Popper's argument scientific theories never can be proved true, but they can be falsified. New theories that solve scientific problems and are not falsified are added to the body of science. That is, employed and "not falsified" is the characterization of fitness in this theory of science. For the most part Campbell treats science as a relatively unified body of doctrine, and his language implies a scientific community together searching after truth, that is of collective evolutionary learning. On the other hand, his theory is compatible with the notion of individual scientists putting forth their particular theories in hope of winning a Nobel prize. A good case can be made that both images of sciencecooperative and competitive-are partly correct (see Hull 1988).

In any case the theory leaves open two questions. The first is what determines which theories are to be rigorously tested, and what is the standing of theories that have not been. "Theories" that have not (as of yet) been subject to rigorous testing do not necessarily have the same standing. Some may never be brought to a serious test simply because they are regarded as irrelevant, or on their face absurd. Others may fit so well with prevailing understanding that they are absorbed without direct testing. The second question is what falsification means; in many cases the conclusions of a test may be ambiguous, or there may be reason to question the way it was run, or whether it was appropriate. Often a theory which seems to fail a test can be patched up with a well crafted modification or amendment. These issues open the door to a much more complicated theory of the evolution of science than at least the simple interpretation of Campbell's.

The "social constructionists" recognize and revel in these complications (see e.g., Bruno Latour 1986). They propose that very few theories, or scientific arguments more generally, are ever completely falsified, or even put to a test that all would regard ex ante as conclusive. Thus scientific opinion is what matters and, in a context where different individuals and groups have different opinions, what is considered scientific fact and is published in reputed journals, taught to graduate students, etc., is largely a matter of scientific politics.

Thomas Kuhn (1970) presents a view somewhat between Campbell and the social constructionists. On the one hand Kuhn proposes that most "normal science" proceeds in almost unthinking acceptance of prevailing theory, and that there is strong built-in disbelicf of results that challenge that theory. On the other hand, also central to Kuhn's theory of the evolution of science is that unanswered questions or anomalies tend to accumulate and, as they do, questions increasingly are asked about the adequacy of prevailing theory. A standard response of the scientific community is to propose modest modifications or additions to prevailing theory. However these may not succeed or the developing theoretical structure may come to be seen as rococo. The seeds then are planted for a scientific revolution.

Neither Campbell nor Kuhn (in their earlier versions) address the issue of competing theories. However, such competition is the heart of scientific revolutions. Imre Lakatos (1970) proposes that broad theories should be regarded as defining research programs. These programs can be judged by the community as proceeding effectively-that is as making good progress-or as more or less stuck. Lakatos proposes that there are almost always competing theories around. The one that defines the more effective research program tends to win out. But again, one can ask what defines "effective." A particular theory almost al- 
ways points to a number of predicted implications, and exploring these defines a variety of puzzles and problems and tasks. A research program may be good in dealing with some of these, and not so effective on others. What counts?

Note that several different "theories" of the evolution of science have been described above. Some are in conflict. In particular the social constructionists would seem at odds with scholars, like Campbell, who believe that new scientific hypotheses, or at least those taken seriously, are subject to test, and that enough of the tests are sufficiently objective and unambiguous to monitor the enterprise. (This also clearly is Hull's view.) Some of the theories are compatible, and can be joined. Thus Kuhn might be regarded as providing an evolutionary theory of science within a given research program, and Lakatos a theory which explains selection among competing programs. Regarding what criteria are used to weigh program effectiveness, later in this essay I shall suggest that part of the answer may reside in the connections between science and technology.

Does science make progress? While the social constructionists seem strongly reserved about this, I think it fair to say that most of the theorists who propose that science evolves believe that the process does generate progress, at least along the lines of research pursued. (This clearly is Hull's view.) While occasionally we delude ourselves that we have understood something when we do not, and often the going toward better understanding is hard, by and large through science we have come to know more and more about nature and how it works. Or at least this is the flavor of most of this body of theorizing.

\section{B. Technology}

A number of analysts have proposed that technology evolves. The analyses of
Nathan Rosenberg (1976, 1982), Christopher Freeman (1987), George Basalla (1988), Joel Mokyr (1990), Nelson and Winter (1977), Dosi (1988), and Walter Vincenti (1990) are strikingly similar in many respects. To keep the discussion below simple, I will follow the discussion of Vincenti.

In Vincenti's theory, the community of technologists at any time faces a number of problems, challenges, and opportunities. He draws most of his examples from aircraft technology. Thus, in a new paper (Vincenti 1994) he observes that in the late 1920 s and early 1930s, aircraft designers knew well that the standard pattern of hooking wheels to fuselage or wings could be improved upon, given the higher speeds planes were then capable of with the new body and wing designs and more powerful engines that had come into existence. They were aware of several different possibilities for incorporating wheels into a more streamlined design. Vincenti argues that trials of these different alternatives were, in the same sense put forth by Campbell, somewhat blind. This is not to say that the engineers thinking about and experimenting with solutions were ignorant either of the technical constraints and possibilities or of what was required of a successful design. Rather, his proposition is that, while professional knowledge and appreciation of the goals greatly focused efforts at solution, there still were a number of different possibilities, and engineers were uncertain about which would prove best, and disagreed among themselves as to where to place bets.

This kind of uncertainty, together with the proposition that uncertainty is resolved only through ex post competiton, is the hallmark of evolutionary theories. In this case it turned out that having the wheel be retractable solved the problem better than did the other alternatives ex- 
plored at that time. Thus, "fitness" here is defined in terms of solving particular technological problems better.

One might propose that identification of this criterion only pushes the analytic problem back a stage. What determines whether one solution is better than another? At times Vincenti writes as if the criterion were innate in the technological problem, or determined by consensus of a technological community who are, like Campbell's community of scientists, cooperatively involved in advancing the art.

However, Vincenti also recognizes that the aircraft designers are largely employed in a number of competing aircraft companies, whose profitability may be affected by the relative quality and cost of the aircraft designs they are employing, compared with those employed by their competitors. But then what is better or worse in a problem solution is determined at least partially by the "market," the properties of an aircraft customers are willing to pay for, the costs associated with different design solutions, etc. In the case of aircraft, the military is an important customer, as well as the airlines. Thus the evolution of aircraft at least partially reflects military demands and budgets, as well as civilian.

As with the case of science, some authors dispute that the evolution of technology follows a path that might be considered as "progress," or even that there are any objective criteria for technological fitness. The book by Wiebe Bijker, Thomas Hughes, and Trevor Pinch (1989) surveys various theories of "social construction" of technology. Michael Tushman and Lori Rosenkopf (1992) develop a more nuanced view of social determinism, but one which also implicitly denies the importance of economic efficiency, save as a gross screen. On the other hand, evolutionary theorists of the development of technology of the Vin- centi camp believe strongly that there is technological progress, and ask the reader who doubts to compare modern aircraft with those of fifty years ago, modern pharmaceuticals with those available before World War II, etc.

In recent years a particular insight or argument has somewhat complicated this discussion. While those that profess that science "progresses" generally seem to have in mind a unitary concept of "truth" toward which science is going, recent scholarship on the evolution of technology has proposed that there may be a number of different evolutionary tracks that go in quite different directions, and that movement down one may block movement down another. Thus the rapid evolution of gasoline-powered automobiles may have improved these, but at the same time may have scotched progress toward battery-powered cars. We will pick up this discussion in Section V.

\section{Business Organization}

Alfred Chandler's research (1962, 1990) has been concerned with understanding how the complex structures that characterize modern multiproduct firms came into existence. For our purposes his story is especially interesting, in that it is a story of coevolution. The coevolution is not of genes and memes, but of technology and business organizations. He argues that a variety of technological developments occurred during the mid and late 19th century which opened up the possibility for business firms to be highly productive and profitable if they could organize to operate at large scales of output, and with a relatively wide if connected range of products. He describes various organizational innovations that were tried, and while his central focus is on those that "succeeded," it is clear from his account that not all did.

Arguing in a manner similar to Vin- 
centi, Chandler's "fitness criterion" is that the new organizational form solved an organizational problem. Presumably the solution to that problem enabled a firm to operate at lower costs, or with greater scale and scope, in either case, with greater profitability. Like Campbell and Vincenti, Chandler clearly sees a community, in this case of managers. But he also sees companies competing with each other. His argument is that companies which found and adopted efficient managerial styles and structural forms early won out over their competitors who did not, or who lagged in doing so. Oliver Williamson (1985), drawing from Chandler, but putting forth a much more explicit formal theory, proposes that a relatively sharp "fitness" criterion determined which organizational forms survived and which ones did not-economic efficiency.

Chandler's and Williamson's accounts of the development of the large multidimensional corporation stress the need of top firm managers concerned with market defined efficiency somehow to decentralize and yet still control large and diversified bureaucracies. Marxians highlight a different aspect of the organizational forms that evolved-that they sharply reduced the importance of workers with special skills, and hence shifted power toward capital. Neil Fligstein (1990) presents a still different view on corporate fitness, which emphasizes responsiveness to changed legal regimes, public policies, and the climate of political opinion more generally toward what corporate action and form ought to be.

As with the case of technology, some recent writing has proposed that the path that has taken us to the modern large hierarchically organized corporation is one we did not have to take, and that in fact better paths existed. We will pick up this theme later.

\section{Law}

The final example treated in this section is the body of theory that proposes that the law evolves. Donald Elliot (1985) has written a rich survey of the various evolutionary theories about law. I focus here on only a small portion of that intellectual tradition.

In particular I will be concerned with the body of theorizing, put forth by scholars such as Harold Demsetz (1967) and William Landes and Richard Posner (1987), that the common law evolves in directions that make it economically efficient. While different authors in this tradition have proposed different mechanisms, in all the decisions to litigate provide the force that gets the law to change. In some versions it is argued that litigation is more prevalent when the law is "inefficient" than when it is efficient, because in the latter cases conflicts are more likely to be settled out of court without any change in the law, although the reasoning behind that proposition is not clear in all accounts. In some versions judges (juries) are inclined to decide cases that do arise in ways that are consistent with economic efficiency, and those judgments in turn modify the common law in that direction. In other versions no such inclination is assumed, but rather cases will continue to be litigated until an "efficient" judgment is made, at which time it will become precedent and litigation will diminish.

Criticizing this simple view of legal evolution, Robert Cooter and Daniel Rubenfeld (1989) emphasize the complex nature of legal disputes and their settlement, involving the actions indviduals take that may risk suit, decisions of potential plaintiffs to assert a legal complaint, bargaining regarding out-ofcourt settlements, and the proceedings of cases that actually get decided in 
court. They express skepticism about whether there are any strong forces leading to efficiency, and argue that, if there are any such strong forces, they must be due to the inclinations of judges. They are skeptical of this too, citing other legal values-like fairness-and also pointing to the fact that judges may have their own interests.

P. Ruben and M. Bailey (1992) recently have proposed an interesting variant on this theme. They note that lawyers have a strong financial interest in the shape of the law, and in particular benefit when the law forces litigation. They go on to propose that the recent shift of legal precedent toward more favorable reception of consumer suits regarding products which cause them harm is, largely, the self-motivated work of lawyers.

Note that the theories discussed above are similar in certain respects, but differ in others. They are similar in that they all are concerned with a particular aspect of culture, and focus on its evolution. They are similar in proposing that the processes that generate new cultural elements or modify old ones are to some extent blind, although the details of these mechanisms differ from case to case, and in some the mutation or innovation mechanisms have strongly directed elements as well as random. However in each of these theories the "selection mechanism" provides a large share of the explanatory power. That is, the power of these theories depends on their ability to specify "fitness" plausibly.

Both neoclassical economists and economists inclined to evolutionary theorizing are prone to look to a market or a market analogue as the mechanism which defines what will "sell," and to "profit" or its analogue as the reward to actors that meet the market test. The theories above clearly differ in the extent to which they can be forced into that mold.

There certainly is no real "market" out there in Campbell's or Kuhn's or Lakatos' theory of science as an evolutionary process, save for the metaphorical "market of scientific judgment." In the cases of technology and the organization of enterprises, a moderately persuasive case can be made that, in many sectors at least, real, not metaphorical, markets have a powerful influence on what is "fit" and what is not, and that profit is an important measure of fitness. However, as we have seen there are dissentors, mainly from outside economics. One important issue is the extent to which competition provides a sharp fitness test in sectors where markets are operative. If it does not there is room for a variety of nonmarket forces to influence what "survives." Also, there are serious questions about the range of sectors-kinds of technologies and organizations-where markets are strongly operative. In the case of military or medical technologies, or military bases or hospitals, it can be argued that market forces are weak, and that the "selection environment" is determined largely by professional judgments, and by political processes that regulate how much professionals in the sector have to spend. The analytic problem, then, is to identify how these forces define "fitness."

The dispute about what determines how the law evolves highlights these kinds of questions. Clearly there is no real "market" out there, but one set of authors argues that market valuation of prevailing law and its alternatives does influence what the law becomes, and strongly. Other authors are not so sure that "efficiency" in an economic sense guides the evolution of the law so much as ideology, or "interests," or "power."

One could take a position that it depends, with sometimes one influence 
prevailing, and sometimes another. However, in the absence of ability to explain or predict what influence will dominate in particular cases, while evolutionary theory may provide a useful language for historical discussion, the theory has little predictive power, and its explanations are at least partially ad hoc.

This would seem to be a big strike against an evolutionary theory of the law, or at least one that is this complex. On the other hand one can argue that the illumination of the complex contingent dependent process by which the law evolves is a strength of the theory. Such an analysis reveals the apparent strong predictive power of a simpler theory-in this case that the law always adjusts so that it is maximally efficient-to be fool's gold. I take it that this is Gould's argument against the proposition that evolution optimizes biological fitness.

However, this kind of understanding of complexity that a good and well-posed evolutionary theory may yield needs to be distinguished sharply from weaknesses in prediction and explanation that stem from the fact that a theory is not coherent. Thus the argument that the law evolves so as to be efficient, for example, is an assertion that may or may not be empirically correct, but which originally was presented with no coherent evolutionary theory behind it. The proposition that litigation stops if and only if the law is efficient may provide part of an evolutionary theoretic basis for such an analytic argument, but that proposition needs more justification than it often is given, and the general argument almost surely needs some other assumptions as well.

In my judgment virtually all of the theories described in this section could benefit from a closer scrutiny and more careful development of their logical structure. I deliberately have not tied the term "formal theory" to the expres- sion of a theory in mathematical or quasi-mathematical terms. Particularly if the logic is relatively simple, expression in careful natural language can be rigorous. But when the logic becomes complex, the advantages of mathematical formulation can be substantial.

Once one is confident that the theory put forth is logically coherent, the central question remains as to whether one finds the theory plausible, given what one knows about the facts of the matter. But evolutionary theories are no different in this regard than any other kind.

\section{Evolutionary Models of Economic Growth Fuelled by Technical Advance}

The body of evolutionary theorizing considered in this section differs from that discussed above in at least three respects. First, the theorizing is more complex in the sense that it involves a number of different variables, and the focus is on their coevolution. Second, the theory is expressed mathematically; in some cases the logical connections are developed as theorems, while in others they are explored through simulation methods.

Third, the evolutionary theories presented here have been put forth by their authors as express alternatives to another theory-in this case neoclassical growth theory-which they regard as too "mechanical." In this sense they represent a deliberate attempt on the part of the authors to move toward Marshall's Mecca.

While concerned with economic dynamics, the kind of analysis contained in neoclassical growth theory almost certainly was among the kind Marshall had in mind when he referred to theories based on mechanical concepts of equilibrium. Within that theory, economic growth is viewed as the moving equilibrium of a market economy, in which 
technical advance is continuously increasing the productivity of inputs, and the capital stock growing relative to labor inputs. These two phenomena together provide the explanation for the increase in labor productivity and per capita income that are the standard measures of growth. Together, in the way the theory is put together, they explain the rise in real wages that has characterized economic growth.

Technical advance is an essential element of the neoclassical account. The last few years have seen a number of interesting proposals to amend the simple neoclassical growth model so as to highlight that technical advance is to a considerable degree endogenous. (For reviews see Paul Romer 1991 and Bart Verspagen 1992.) However these "new" neoclassical models are "mechanical" in the same sense as are the old ones. They do not address the problems with neoclassical growth theory felt by the authors of evolutionary alternatives.

In particular, as we have noted, virtually all serious scholars of technical advance have stressed the uncertainty, the differences of opinion among experts, the surprises, that mark the process. Mechanical analogies involving a moving equilibrium in which the actors always behave "as if" they knew what they were doing seem quite inappropriate. Most knowledgeable scholars agree with Vincenti that the process must be understood as an evolutionary one. The challenge faced by the authors considered in this section has been to devise a theory of growth in which technical advance and capital formation together drive growth, as in neoclassical growth theory, and which is capable of explaining the observed macroeconomic patterns, but on the basis of an evolutionary theory of technical change rather than one that presumes continuing equilibrium.

Without any exception I know about, the evolutionary theories of economic growth that have been developed all draw inspiration from Joseph Schumpeter's Capitalism, Socialism and Democracy (1976, first published 1942). In that work, Schumpeter developed a theory of endogenous technological advance, resulting from the investments made by business firms to best or stay up with their rivals. The earliest class of formal evolutionary growth models based on these ideas was developed by Winter and myself (1974), and because it has provided much of the base for subsequent work, I shall concentrate on it. However I also will consider variants or extensions that have been developed by others.

In these models, firms are the key actors, not individual human beings. Of course (implicitly) firms must provide sufficient inducements to attract and hold the individuals that staff them. But within these models, individuals are viewed as interchangeable and their actions determined by the firms they are in.

In turn, the firms in these models are, from one point of view, the entities that are more or less fit, in this case more or less profitable. But from another point of view firms can be regarded as merely the incubators and carriers of "technologies" and other practices that determine "what they do" and "how productively" in particular circumstances. Winter and I have used the term "routines" to denote these. The concept of routines is analytically similar to the genes in biological theory, or the memes or culturgens in sociobiology.

The term "routine" connotes, deliberately, behavior that is conducted without much explicit thinking about it, as habits or customs. On the other hand, within these models routines can be understood as the behaviors deemed appropriate and effective in the settings where they are invoked. Indeed they are the product of 
processes that involve profit-oriented learning and selection. Metaphorically, the routines employed by a firm at any time can be regarded as the best it "knows and can do." To employ them is rational in that sense, even though the firm did not go through any attempt to compare its prevailing routines with all possible alternative ones. Whether that translates into "optimizing" behavior depends on what one means by that term. (For a fine discussion of this issue in biology and in economics, see Paul Schoemaker 1991.)

These models generally involve three different kinds of firm "routines." First, there are those that might be called "standard operating procedures," those that determine how and how much a firm produces under various circumstances, given its capital stock and other constraints on its actions that are fixed in the short run. Prominent among these are technologies. Second, there are routines that determine the investment behavior of the firm, the equations that govern its growth or decline (measured in terms of its capital stock) as a function of its profits, and perhaps other variables. Third, the deliberative processes of the firm, those that involve searching for better ways of doing things, also are viewed as guided by routines. While in principle within these models search behavior could be focused on any one of the firms prevailing routines-its technologies, or other standard operating procedures, its investment rule, or even its prevailing search procedures-in practice, in all of them search is assumed to be oriented to uncover new production techniques or to improve prevailing ones. Winter and I have found it convenient to call such search R \& D. Other authors of similar models have invoked the term "learning" to describe analogous "improvement" processes.

Firm search processes provide the source of differential fitness; firms whose R \& D turn up better technologies will earn profits and grow relative to their competitors. But R \& D also tends to bind firms together as a community because in these models a firm's R \& D partly attends to what its competitors are doing, and profitable innovations are, with a lag, imitated by other firms in the industry.

The firm, or rather the collection of firms in the industry, perhaps involving new firms coming into the industry and old ones exiting, is viewed as operating within an exogenously determined environment. The profitability of any firm is determined by what it is doing, and what its competitors do, given the environment. Generally the environment can be interpreted as a "market," or set of markets.

Note that in the theory that has been sketched above, just as routines are analogous to genes, firms are analogous to phenotypes, or particular organisms, in biological evolutionary theory, but there are profound differences. First, firms do not have a natural life span, and not all ultimately die. Neither can they be regarded as having a natural size. Some may be big, some small. Thus in assessing the relative importance of a particular routine in the industry mix, or analyzing whether it is expanding or contracting in relative use, it is not sufficient to "count" the firms employing it. One must consider their size, or whether they are growing or contracting. Second, unlike phenotypes (living organisms) that are stuck with their genes, firms are not stuck with their routines. Indeed they have built in mechanisms for changing them.

The logic of these models defines a dynamic stochastic system. It can be modeled as a complex Markov process. A standard iteration can be described as follows. At the existing moment of time 
all firms can be characterized by their capital stocks and prevailing routines. Decision rules keyed to market conditions look to those conditions' "last period." Inputs employed and outputs produced by all firms then are determined. The market then determines prices. Given the technology and other routines used by each firm, each firm's profitability then is determined, and the investment rule then determines how much each firm expands or contracts. Search routines focus on one or another aspect of the firm's behavior and capabilities, and (stochastically) come up with proposed modifications which may or may not be adopted. The system is now ready for next period's iteration.

The theory described above can be evaluated on a number of counts. One is whether the view of behavior it contains, in abstract form, is appealing given what it purports to analyze. The individuals and organizations in these models act, as humans do in the models of sociobiology, on the basis of habits or customs or beliefs; in the Nelson-Winter model all these define routines. While firm routines can be regarded as the result of a learning process, the implicit "rationality" in these models certainly is a "bounded" one, in the sense of Simon (1947) and James March and Simon (1958). As we shall see, it is quite possible to build a certain amount of foresight into the actors of an evolutionary theory. However if one wants a model in which it is presumed that the actors largely understand the details of the context in which they are operating and competing, save for the truly stochastic elements, and are able to choose their best action in the light of this full knowledge, one might as well use a full-blown neoclassical rational choice model. This of course is what is done in the new neoclassical growth theories.
The theory can be judged by the appeal of the theory of technical progress built into it. The view is certainly "evolutionary," and in that regard squares well with the accounts given by scholars of technical advance like Vincenti, at least in abstract forms. It must be noted that, within the theory, "evolution" is going on at several different levels. New technological departures are being generated by individual firms, which in effect "select" on them deciding which to introduce and which not to. (For an empirical study of evolution within a firm see Robert Burgelmam 1993.) Firms also are, by scanning their competitors' technologies, deciding which of these to take aboard and which not. In addition, there is market selection on firms that are doing well.

Within this class of models, "profitability" determines the "fitness" of technology, and of firms, and firms are the only organizational actors. These observations call attention to the fact that this theory would seem to apply only to economic sectors where the market provides the (or the dominant) selection mechanism winnowing on technologies and firms. It is not well suited for dealing with sectors like medical care, or defense, where professional judgments, or political process, determine what is fit and what is not. Selection environments clearly differ from sector to sector, and it would seem that these differences need to be understood and built into sectoral level analyses. (For an elaboration of this point, see Nelson and Winter 1977.)

However the central purpose of the models considered in this section is to explain economic growth at a macroeconomic level. Thus a fundamental question about them is this. Can they generate, hence in a sense explain, the rising output per worker, growing capital intensity, rising real wages, and a rela- 
tively constant rate of return on capital, that have been the standard pattern in advanced industrial nations and what neoclassical growth theory seems to explain? The answer is that they can, and in ways that conform well with underlying appreciative theory.

Within these models a successful technological innovation generates profits for the firm making it, and leads to capital formation and growth of the firm. Firm growth generally is sufficient to outweigh any decline in employment per unit of output associated with productivity growth, and hence results in an increase in the demand for labor, which pulls up the real wage rate. This latter consequence means that capital using but labor saving innovations now become more profitable, and when by chance they appear as a result of a "search," they will be adopted, thus pulling up the level of capital intensity in the economy. At the same time that labor productivity, real wages, and capital intensity are rising, the same mechanisms hold down the rate of return on capital. If the profit rate rises, say because of the creation of especially productive new technology, the high profits will induce an investment boom, which will pull up wages, and drive capital returns back down.

These deductions of evolutionary growth theory would not surprise an advocate of neoclassical theory. On the surface they appear similar to those of neoclassical growth theory. Indeed for evolutionary theory to have credibility these predictions had better be similar, because any broad growth theory needs to be consistent with the basic empirically documented broad features of economic growth as we have experienced it. However, while at first glance the mechanisms explaining these patterns have a certain surface similarity in evolutionary and neoclassical theory, if one looks beneath the surface one can see that the mechanisms in fact are very different. In particular, one theory is based on the "conception" of a moving equilibrium, and the other most emphatically is not.

And if one takes a closer look, it becomes clear that evolutionary theory enables one to see, to expect, phenomena to which neoclassical theory is blind, or denies. At the same time that the model generates "macro" time series that resemble the actual data, beneath the aggregate at any time there is considerable variation among firms in the technologies they are using, their productivity, and their profitability. Within this model more productive and profitable techniques tend to replace less productive ones, through two mechanisms. Firms using more profitable technologies grow. And more profitable technologies tend to be imitated and adopted by firms who had been using less profitable ones. Thus the theory is consistent with both the large body of empirical work that has documented considerable and persistent intra-industry inter-firm dispersion (e.g., Richard Rumelt 1991 and Mueller 1989) and with what is known empirically about the diffusion of new techniques (see e.g., Stanley Metcalfe 1988). Neoclassical growth theories have trouble being consistent with these elements of economic growth as we have experienced it.

Luc Soete and Roy Turner (1984), Metcalfe (1988, 1992), and Metcalfe and Michael Gibbons (1989) have developed evolutionary growth models focusing on diffusion, in the sense above. These authors repress the stochastic element in the introduction of new technologies that was prominent in the models described above and, in effect, work with a given and fixed set of technologies. However, within these models each of the individual technologies may be improving 
over time, possibly at different rates. At the same time, firms are tending to allocate their investment portfolios more heavily toward the more profitable technologies than toward the less. As a result, rising productivity in the industry as a whole, and measured aggregate "technical advance," is the consequence of two different kinds of forces. One is the improvement of the individual technologies. The other is the expansion of use of the more productive technologies relative to the less productive ones.

Both groups of authors point out that the latter phenomenon is likely to be a more potent source of productivity growth when there is prevailing large variation in the productivity of technologies in wide use, than when the best technology already dominates in use. Thus the aggregate growth performance of the economy is strongly related to the prevailing variation beneath the aggregate.

The model by Gerald Silverberg, Dosi, and Luigi Orsenigo (1988) develops the basic theoretical notions introduced in this section in another direction. In their model there are only two technologies. One is potentially better than the other, but that potential will not be achieved unless effort is put into improving prevailing practice. Rather than incorporating a separate "search" activity, in Silverberg et al. a firm improves its prevailing procedures (technologies) through learning associated with operation. What a firm learns is reflected in its increased productivity in using that technology, but some of the learning "leaks out" and enables others using that technology to improve their productivity for free, as it were.

In contrast with the other models considered in this section where firms do not "look forward" to anticipate future developments, in the model of Silverberg et al., firms, or at least some of them, recognize that the technology that initially is behind in productivity is potentially the better technology, and also that they can gain advantage over their competitors if they invest in using and learning with it. In contrast with the Nelson-Winter model, a firm may employ some of both technologies, and hence may use some of its profits from using the prevailing best technology to invest in experience with presently inferior technology that is potentially the best. If no firm does this, then of course the potential of the potentially better technology never will be realized.

An early "innovator" may come out a winner, if it learns rapidly, and little of its learning "spills out," or its competitors are sluggish in getting into the new technology themselves. On the other hand, it may come out a loser, if its learning is slow and hence the cost of operating the new technology remains high, or most of its learning "spills out" and its competitors get in in a timely manner, taking advantage for-free of the spillover.

Several other evolutionary growth models have been developed. Gunnar Eliasson and colleagues have been constructing over the years a very detailed evolutionary model calibrated on the Swedish economy. (See Eliasson's chapter in Day and Eliasson 1986.) Francesca Chiaramonte and Dosi (1993) recently have blended into the Silverberg-DosiOrsenigo model elements of the NelsonWinter assumptions about stochastic search for new techniques. Katsuhito Iwai (1984) and John Conlisk (1989) also have published models in this class. There clearly is a lot of richness in these "Schumpeterian" models of economic growth, and I believe a lot of potential. It remains to be seen how many economists studying economic growth using the "old" theoretical technology will be attracted to gamble on the new. 
V. Path Dependencies, Dynamic Increasing Returns, and the Evolution of Industry Structure

The models considered in Section IV go a certain distance toward consistency with the appreciative theoretic accounts of long run economic change, but there still is a lot that is "mechanical" about them. Certain variables grow over time, in particular output per worker and real wages. Others remain more or less constant, like the rate of return on capital and factor shares, or at least show no systematic drift. However by and large nothing goes on that could be called "development." While industry may become more concentrated over time, there are no major changes in industry structure of the sort often highlighted in economic histories. No radically new technologies emerge, no new institutions.

The evolutionary theories considered in this section have more of a developmental flavor. They involve path dependencies, dynamic increasing returns, and their intereaction.

Path dependencies are built into all of the models considered above, and dynamic increasing returns (which is one way path dependency may emerge) into some. Thus in virtually all of the models, the particular firms that survive in the long run are influenced by events, to a considerable extent random, that happen early in a model's run. To the extent that firms specialize in particular kinds of technology, what technologies survive is influenced similarly by early random events. In some of the models, "dynamic increasing returns" makes path dependency particularly strong. Thus in Silverberg, Dosi, and Orsenigo the more a firm uses a technology the better it gets at that technology. More, some of the learning "spills over" to benefit other firms using that particular technology. Thus the more a technology is used, the better it becomes vis àvis its competitors.

But while path dependencies and dynamic increasing returns are built into most of the models we already have considered, this was not the center of attention of the authors. Over the past few years, however, a considerable literature in evolutionary economics has grown up focused on these topics. The works of Brian Arthur (1988, 1989) and Paul David $(1985,1992)$ are particularly interesting. My treatment here will aim to generalize the issues they address.

\section{A. Technology Cycles and Dominant Designs}

I begin by considering models that focus on competition among technologies. Students of technical advance long have noted that, in the early stages of a technology's history, there usually are a number of competing variants. (For a fine discussion and a number of illustrative case studies see James Utterback 1994.) Thus in the early history of automobiles, some models were powered by gasoline fuelled internal combustion engines, some by steam engines, some by batteries. As we know, gradually gasoline fuelled engines came to dominate and the other two possibilities were abandoned.

The standard explanation for this is that gasoline engines were the superior mode, and with experience that was found out. The Silverberg, Dosi, and Orsenigo paper contains a model of this mechanism. In their analysis a potentially superior new alternative requires some development-learning-before its latent superiority becomes manifest. It can take time before that development occurs and, with bad luck, it even is possible that it never occurs. But by and large the potentially better technology will win out.

In the Arthur and David models, one can see a different explanation for why 
the internal combustion engine won out. It need not have been innately superior. In these models there are dynamic increasing returns, in that the more a particular technology is employed, the greater its attractiveness relative to its competitors. Thus in the case in question, all that would have been required for the gasoline engine to come to dominate was a run of luck. For some chance reason it gained an initial lead, and this started a rolling snowball mechanism.

What might lie behind an increasing returns rolling snowball? Arthur, David, and other authors suggest several different possibilities.

One is that each of the competing technologies involved is what Winter and I have called a cumulative technology. In a cumulative technology, today's technical advances build from and improve upon the technology that was available at the start of the period, and tomorrow's in turn builds on today's. The cumulative effect is like the technology specific learning in the Silverberg et al. model.

Thus according to the cumulative technology theory, in the early history of automobiles, gasoline engines, steam engines, and electrical engines, might all have been plausible alternative technologies for powering cars. While we now know that gasoline engines became dominant, according to this theory this might have been simply a matter of luck. By chance inventors tended to concentrate on it, or by chance big advances were made. However, once the gasoline engine had been developed to a point where it was significantly superior to extant steam or electrical engines, investing time and resources to advance these other technologies came to appear a bad bet, because such a large gap in performance needed to be made up before they would be competitive.

There are two other dynamic increasing returns stories that have been put forth. One stresses advantages to consumers or users if different individuals buy similar, or compatible productsthis has been called network externalities-which lend advantage to a variant that just happens to attract a number of customers early. The other stresses complements, for example where a particular product has a specialized complementary product or service, whose development may lend that variant special advantages. Telephone networks, in which each user is strongly interested in having other users have compatible products, is the most commonly employed example of the first case. Video cassette recorders which run cassettes that need to be specially tailored to their particular design, or computers that require compatible software, are often used as examples of the second. (For a very good general discussion and review of the literature on both of these stories, see Michael Katz and Carl Shapiro 1994.)

However, while the stories are different, the mathematics used to formalize them tends to be the same. (See e.g., Arthur 1988.) Also, the phenomena often are intertwined, and also linked with the processes involved in the development of cumulative technologies, as in David's (1985) example of the QWERTY typewriter keyboard.

Thus to return to our automobile example, people who learned to drive in their parents' or friends' car powered by an internal combustion engine almost certainly were drawn to similar cars when they themselves came to purchase one, in part to avoid the new learning and potential surprises that would be involved if they bought a steam or electric powered one. At the same time the ascendancy of automobiles powered by gas burning internal combustion engines made it profitable for petroleum companies to locate gasoline stations at convenient places along highways. It also made 
it profitable for them to search for new sources of petroleum, and to develop technologies that reduced gasoline production costs. In turn, this increased the attractiveness of gasoline powered cars to car drivers and buyers.

Note that, for those who consider gas engine automobiles, large petroleum companies, and the dependence of a large share of the nation's transportation on petroleum, a complex that lies behind many social ills, the story spun out above indicates that "it did not have to be this way." If the roll of the die early in the history of automobiles had come out another way, we might today have had steam or electric cars. A similar argument recently has been made about the victory of A.C. over D.C. as the "system" for carrying electricity (for an openminded discussion see David 1992). The story also invites consideration of possibly self-interested professional judgments or political factors as major elements in the shaping of long run economic trends, a subject we will pick up shortly. After all, under these theories all it takes may be just a little push.

On the other hand, other analysts may see the above account as overblown. Steam and battery powered car engines had major limitations then and still do now; gasoline clearly was better. A.C. had major advantages over D.C., and still does. According to this point of view dynamic increasing returns is an important phenomenon, but it is unlikely that it has greatly influenced which technology won out, in most important cases. I predict that this issue will be a lively topic of empirical research and argument over the coming years.

There also is a more general open question about the range of technologies where a "dominant design" emerges, for any reason. The various dynamic increasing returns stories seem plausible for some product classes, but not for others.
And in some product class areas different user needs may tend to prevent a particular product from coming to dominate the market, even if there are dynamic increasing returns. Pharmaceuticals, the value of which are extremely sensitive to both the particular disease and the particular characteristics of the patient, are a good case in point.

\section{B. Firm and Industry Structure}

I turn now to a different but related body of evolutionary writings-that concerned with the evolution of industry structure as a technology develops. It is tied to the notion that in most technologies after a period of time a dominant design emerges, but is not committed to any particular theory of how that happens, whether because the truly better variant is finally found and consensus develops around it or because of dynamic increasing returns phenomena. In any case, within this body of evolutionary theorizing, the establishment of a dominant design has important implications regarding the subsequent nature of $\mathrm{R} \&$ $\mathrm{D}$, and for industry structure.

The basic argument would appear to have two sources. The first is Mueller and Tilton (1969), based on their speculations about patterns of industry evolution they were observing. The second was William Abernathy and Utterback (1975) based on their detailed study of automobiles. Because the Abernathy and Utterback story is closely linked to an interesting theory of what happens to R \& $\mathrm{D}$ as a dominant design emerges, I will follow it.

The basic proposition is that, prior to the emergence of a dominant design, there is little $\mathrm{R} \& \mathrm{D}$ directed toward improving production processes, because product designs are unstable, and the market for any one is small. With the emergence of a dominant design, the profits from developing better ways of 
producing it become considerable. Often the development of better production processes will involve the exploitation of latent scale economies, and the establishment of capital intensive modes of production. In turn, the improvement of production processes that are specific to a particular broad design further locks it in, and disadvantages competing designs.

The argument then is that this pattern of technological evolution causes a particular pattern of evolution of firm and industry structure. In the early stages of an industry-say automobiles-firms tend to be small, and entry relatively easy, reflecting the diversity of technologies being employed, and their rapid change. The industry consists of a number of smallish firms, but with a lot of entry and exit. As the quality of the products improve, and the market grows, so do the number of firms active in the industry. However, as a dominant design emerges, and specialized production processes are developed, barriers to entry begin to rise as the scale and capital needed for competitive production grows. Also, with the basic technology set, learning becomes cumulative, and incumbent firms are advantaged relative to potential entrants for that reason as well. After a shake out, industry structure settles down to a collection of established largish firms.

When this theory was first put forth, there was only limited data supporting it. Since that time Michael Gort and Steven Klepper (1982), Klepper and Elizabeth Graddy (1990), Utterback and Fernando Suarez (1993), Utterback (1994), and Franco Malerba and Orsenigo (1993, 1994) have provided convincing evidence that this pattern of evolution in fact holds over a wide range of industries.

A recent formal model developed by Klepper (1993) accepts the broad em- pirical story, but puts forth a different evolutionary theory to explain it. In Klepper's model the investments made by a firm in product innovation are independent of firm size, but investments in process innovation are positively related to firm size. As in the more standard story, in the early days of a technology's history, firms are small, for that reason little process $R$ \& $D$ is done, and entry barriers are low. The presence of many firms makes for rapid product innovation. But as profitable extant firms grow and invest more in process innovation, entry barriers rise. Shake out occurs because of rivalry among the extant firms, increasingly competing on the basis of cost. No dominant design emerges in the Klepper model, but as the number of extant firms dwindles, product innovation slows.

\section{Supporting Institutions}

The writing on the coevolution of technology and industry structure tends to define industry structure rather conventionally. However, there are a number of studies which define industry structure more broadly, or look outside the industry, narrowly defined, and are concerned with the coevolution of a technology and industry with various supporting institutions.

As an industry becomes established, one frequently observes not only the development of technical and product standards, but also the emergence of standard patterns of interaction more generally between firms, suppliers, and customers, and across firms in the industry. Economic relations become embedded in social ones, along the lines described by Mark Granovetter (1985), and people become conscious that there is a new industry, and that it has collective interests and needs. Michael Hannan and Glenn Carroll discuss in some detail these processes of "legitimation" and 
their consequences. See also Bennett Harrison (1992). Industry or trade associations form. These give the industry a recognized organization that can lobby on its behalf for regulation to its liking, for protection from competition from outside the group, for public programs to support it, etc. This is another feature of an industry's evolution that can lock in the status quo.

More generally, while the formal evolutionary growth models of Section IV, and the dynamic increasing returns models discussed at the beginning of this section, take the basic parameters of the "selection environment" (usually treated as a market) as given, many of the sociologists studying industry evolution stress that the industry itself strongly molds its own selection environment. It does so through the rules of behavior and interaction among firms that evolve spontaneously, through the formation of a variety of industry-related organizations that decide matters like standards, and through political action. (See e.g., Michael Tushman and Elaine Romanelli 1985; and Rosenkopf and Tushman 1994.) In turn such action may be central in determining what design or system turns out to be dominant. (For such a discussion bearing on electric power systems, see Patrick McGuire, Granovetter, and Michael Schwartz 1993.)

If the technology on which the industry is based has novel characteristics, new technical societies and new technical journals, tend to spring up. In some cases whole new fields of "science" may come into being (Rosenberg 1982, ch. 7; and Nelson and Rosenberg 1993). Thus the field of metallurgy came into existence because of a demand for better understanding of the factors that determined the properties of steel. Computer science was brought into existence by the advent of the modern computer. Chemical engineering and electrical en- gineering rose up as fields of teaching and research because of industry demand for them that occurred after the key technological advances that launched the industries. Earlier I noted the apparent blindness of much of the writing on how science evolves to the use of science in technology. The technology-oriented sciences directly provide a "market like" environment stimulating research on various topics and also a stringent test environment for new scientific theories and other published findings.

The emergence and development of these technology-oriented sciences tend to tie industries to universities, which provide both people trained in the relevant fields, and research findings which enable the technology to advance further. The development of these sciences naturally lends extra strength to prevailing technologies. On the other hand the presence of university research tends to dilute the extent to which firms in being have knowledge advantages over potential entrants. Also, research at universities just may become the source of radically different technological alternatives.

Recognition of the role of technical societies and universities in the development of modern technologies opens the door to seeing the wide range of institutions that may co-evolve with a technology and an industry. Often legal structures need to change. Thus there may be intellectual property rights issues that need to be sorted out-bio-technology is a striking contemporary case in point. There almost always are issues of regulation, as was prominently the case in radio and, in a different manner, biotechnology again. Hughes (1983) has described in great detail the wide range of legal and regulatory matters that had to be decided before electric power could go forward strongly, and how the particular ways they were decided affected the evolution of the technology 
and the industry. The coevolution of law and technology and industry structure has been only lightly touched in the writings on how the law evolves.

In many cases new public sector activities and programs are required. Thus mass use of automobiles required that societies organize themselves to build and maintain a system of public roads. Airplanes required airports. The development of radio, and of commercial television, required mechanisms to allocate the radio spectrum.

These examples indicate that the evolution of institutions relevant to a technology or industry may be a very complex process involving not only the actions of private firms competing with each other in a market environment, but also organizations like industry associations, technical societies, universities, courts, government agencies, legislatures, etc. In turn, the way these other organizations evolve and the things they do may profoundly influence the nature of the firms and the organization of industry. Thus Michael Piore and Charles Sabel (1984) have proposed that the organization of manufacturing activity through large vertically integrated firms, which came to be the norm in many U.S. industries in the early decades of the twentieth century, was not inevitable, but was drawn by the broader institutional context of the U.S. We might instead have organized production in many of these industries through a more fluid structure of networked small and medium-sized firms. (See also Sabel and Jonathan Zeitlin 1993.) In the view of these authors, the U.S. might be in better shape now had the latter been the case.

\section{Responding to the Winds of Change}

Evolutionary theory in biology provides a sharp answer to the question of how life responds in situations where major environmental changes make existing dominant life forms ill adapted. To the extent that better adapted life forms are present in at least small numbers, these and their similar offspring will thrive and multiply, and their now poorly adapted peers will tend to die out. Some new varieties created through mating or mutation that would have had no chance in the old regime, may do well in the new one. Others that would have prospered now may have no chance.

How is it in economics? If one considers "firms" or other organizations as carriers of basic practices-earlier I called them routines-what happens when the market or something else changes? A fundamental difference between organizations and organisms, of course, is that the former are not stuck with their routines but can change them, while the latter cannot change their genes. Thus, unlike the case in biology, it is meaningful in economic evolutionary theory to ask about the extent to which significant adjustment to changed environmental conditions-for example a sharp change in patterns of consumer demands, or factor availabilities and prices, or the advent of radically new technology-is achieved largely by old organizations learning new ways, or requires the death of old organizations, and the birth of new ones.

Some of the organizational ecology models developed by sociologists take a position that firms are like biological organisms. Thus Michael Hannan and John Freeman (1989) posit (for the purposes of their formal theorizing) that organizations cannot change their ways at all. Under this view society's ability to respond to change depends entirely on the presence at any time of a variety of organizations, or the generation of new ones. (For more eclectic surveys of sociological approaches to the evolution of or- 
ganizations, see Howard Aldrich 1979; W. Richard Scott 1992; and Joel Baum and Jitendra Singh 1994.)

While this position may sound bizarre to many economists, a number of careful students of firm behavior have been impressed that the set of things a firm can do well at any time is quite limited, and that, while firms certainly can learn to do new things, these learning capabilities also are limited. Thus Mueller (1989), Karel Cool and Dan Schendel (1988), and Rumelt (1991) have shown that, within an industry, there tends to be persistent differences across firms in profitability or productivity. While "imitation" is an important economic phenomenon, there would appear to be durable firm differences, associated with unique resources or competences. Dosi, David Teece, and Winter (1992) have developed an argument that, to be effective, a firm needs a package of routines, including those concerned with learning and innovation, that are "coherent." But that coherency, on the other hand, entails a certain rigidity.

Paul Milgrom and John Roberts (1990), commenting on a wide range of recent literature on firm competences, have stressed that competences tend to come in strongly complementary packages of traits. As Daniel Levinthal (1994) argues, this undoubtedly is an important reason that successful firms often are difficult to imitate effectively, because to do so requires that a competitor adopt a number of different practices at once. It also is an important reason why firms who do well in one context may have great difficulty in adapting to a new one.

Winter and I (1977, 1982) and Dosi $(1982,1988)$ have used the concept of technological regime or paradigm to refer to the set of understandings about a particular broad technology that are shared by experts in a field, including understandings about what a firm needs to be doing to operate effectively in that regime. Tushman and Anderson (1986) have coined the term "competence destroying technical advance" to characterize new technologies when the skills and understandings needed to deal with them are significantly different from those relevant to the old. There is now considerable evidence (see e.g., Tushman and Anderson 1986; Utterback 1994; Clayton Christensen and Richard Rosenbloom, forthcoming; Rebecca Henderson and Kim Clark 1990; and Henderson 1993) that when such a new technology comes along, the old entry barriers fall down, new companies enter, and many old ones fail. Thus organizations may be more like organisms than many economists are wont to believe, and significant economic change like significant biological change may involve large elements of creative destruction.

What about the institutions that support a particular industry or technology? Can the old ones change to meet the changed needs, or must a basically new set come into existence? If the latter is the case, does this tend to involve the ascendancy of new regions or nations, and the decline of the old? William Lazonick (1990) among others has argued that the broad organization of work and institutions for training labor that worked so well for British industry in the late nineteenth century became a handicap in the twentieth. Thornstein Veblen's famous essay (1915) on the rise of Germany as an economic power stresses more generally that British industry was sorely handicapped in adopting the new technologies that were coming into place around the turn of the century by an interlocking set of constraints associated with her institutions and past investments, whereas Germany could work with a relatively clean slate. 
Recently these ideas have been revisited by Carlotta Perez (1983) and C. Freeman (1991), who have developed the concept of a "techno-economic paradigm." Their argument starts along lines developed by Schumpeter many years ago: different eras are dominated by different fundamental technologies. They then propose that to be effective with those technologies a nation requires a set of institutions compatible with and supportive of them. The ones suitable for an earlier set of fundamental technologies may be quite inappropriate for the new. Perez and Freeman propose that the period since 1970 has seen the rise of "information technologies" as the new basis of economic effectiveness, and argue that effective accommodation requires a very different set of institutions than those required in the earlier era. Japan they see as coming closest to having them. Other but related explanations of the rise of Japan, and the decline of the U.S., but focusing on characteristics of Japanese firms, and their determinants, have been put forth by Masahiko Aoki (1990) and Ronald Gilson and Mark Roe (1993). The Piore and Sabel (1984) argument about the institutional forces that led to the particular structuring of American firms is about the other side of this story.

Over the last several decades a number of biological evolutionary theorists have proposed that in biology evolution often follows the pattern of "punctuated equilibrium." Periodically there are bursts of mutations that somehow take hold, and a new species emerges. There follows a period during which the species evolve rapidly into a form that, then, seems to stabilize. Then in some cases, a new species emerges that replaces the old. The foregoing analysis suggests that, like species, the pattern of evolution of technology linked institutional forms often is that of punctuated equilibrium.

\section{Economic Institutions and Their Evolution}

Two somewhat different intellectual streams have fed into the renewed interest economists have taken in institutions. Economists long have looked to differences across nations in their basic institutions as an explanation for differences in economic performance and living standards (see Hodgson 1988, for a fine review of the "old" institutional economics), and in recent years that interest has intensified. For the most part until recently research along these lines has been empirical, with the theorizing appreciative. Recently that empirically motivated theorizing has become more formal. Also, over the past fifteen years or so, game theorists have come to be interested in "institutions," associating them theoretically with a particular solution of games that have multiple Nash equilibria. That is, the pattern of behavior associated with an equilibrium is seen as "institutionalized." In turn, this intellectual development has had a strong influence on the empirically oriented theorizing.

One issue that has plagued both old and new research on institutions and their evolution has been how to define institutions. The term has been used to cover a grab bag of varied things. Some writers, particularly the older generation of institutional economists, have used the term to refer to what the theorists of cultural evolution, discussed above, would call "culture," or more specifically to those aspects of culture that affect human and organizational action. Under this perspective institutions refer to the complex of socially learned and shared values, norms, beliefs, meanings, symbols, customs, and standards that delineate the range of expected and accepted behavior in a particular context. This view of institutions is alive and well in 
modern sociology. (See in particular Walter Powell and Paul Di Maggio 1991.)

The "new" economic institutionalists have a different intellectual starting place, and as noted above have borrowed extensively from game theory. Thus Douglass North (1990) has proposed that institutions are "the rules of the game." (See also Thrainn Eggerston 1990.) The argument then is that, given the motivations of individuals and organizations and technological or other constraints, "the rules of the game" determine how and why it is played as it is. Andrew Schotter (1981), recognizing that games may have multiple equilibria, has suggested that institutions define "How the game is played" (see also Robert Sugden 1989). Thus the concept here includes not only the rules, but also the standard and expected patterns of actual play that have evolved, which define the constraints and expectations of the present players. It is this concept of institutions that has become prevalent in evolutionary game theory. , While developed in a different way, the game theoretic view of institutions has much in common with the sociological. What is different is the stress by sociologists on norms and belief systems rationalizing action in a given context, whereas the emphasis in game theory is on the self-enforcing nature of institutionalized behavior. It should be noted that North is very close to the sociologists here.

On the other hand, most historical accounts of institutions refer to more concrete things: the form of the modern corporation, or the modern research university, the financial system, and the particular kind of money in use, the court system, a nation's basic legal code, etc. Alessandra Casella and Bruno Frey (1992) use the term "institution" to refer to particular structures and bodies of law like GATT, which define a kind of public order. How do these two apparently different notions about institutions relate?

It is not totally clear, but North makes a distinction between what prevailing institutions in his broad sense allow or require, and particular realizations within the set of the institutionally possible. Thus I understand him as taking a position akin to Durham's regarding culture, that institutions, as he defines them, influence and constrain, but leave considerable room for variability in the way society actually organizes itself. Along these lines one can, as Williamson (1985), see the $M$ form of organization of multi-product firms as, during the period from 1920 to 1970 , a prevailing institution, defining the expectations and norms for such firms. IBM and GM were organizational exemplars of these norms, and as such often referred to as institutions. However, according to this interpretation the "institution" is really defined by the pattern and the norms. Similarly, during the 1960s and 1970s Harvard and the University of California were institutional exemplars of what was widely accepted research universities should be. In the same vein, the IMF, and GATT, were particular organizations, but also representing institutions, in being the particular manifestation of a set of norms and beliefs.

I confess uneasiness at the broad and roomy definition of institutions invoked by the old institutionalists, and my uneasiness here carries over to the modern practice of calling any widespread practice, that can be interpreted as the equilibrium of a game, an institution. But here I put these concerns aside and reflect on the proposition that, however they may be defined, the institutions we now have came about as a result of an evolutionary process.

Abstracting from the enormous diversity of things that have been called institutions, there are several key matters 
that I believe any serious theory of institutional evolution must address. One is path dependency. Today's "institutions" almost always show strong connections with yesterday's, and often those of a century ago, or earlier.

A second is that it almost certainly is necessary to think of evolutionary "processes" in the plural. Different kinds of institutions eyolve in different ways. The earlier generation of institutional economists tended to stress the role of express collective decision making. The present generation tends to stress unplanned self-organization. In many cases the evolutionary processes at work seem to involve a blend of market, professional, and political processes, and it is likely an enormous task to sort these out and get an accurate assessment of operative "fitness" criteria and selection mechanisms.

One virtue of recognizing evolutionary theorizing as a class is that this encourages the application of what is learned in analysis of one topic to analysis of others. The intellectual traverse taken by North is quite interesting in this regard. In his early work on economic institutions (Lance Davis and North 1971), North's position was that, despite the fact that interested parties often differed in their goals, and despite the fact that collective political processes often were involved centrally in the process of institutional evolution, evolution did assure something like optimality. On the other hand, in his recent writings (North 1990), he draws lessons from the above learning and distances himself sharply from any position along side Pangloss. His central argument is this. First, the major differences among nations in economic performance largely are due to differences in their institutions and how they have evolved. While nowhere can they be regarded as optimal, in some countries they have evolved in a way that is favorable to economic progress and in other countries not. Second, the advanced industrial nations have been extremely fortunate in this regard; one cannot attribute their relative well being to any special virtue and wisdom but rather to cultural and political contingencies.

Friedrich Hayek (1988) long has stressed the evolutionary character of the way modern economic institutions have developed, using the following argument. The structure of prevailing institutions is far too complex for human beings to comprehend, hence there is no way people could actually have designed them. More, to think that we could, or that we can scrap them and replace them with something we can plan that would be better, is a "Fatal Conceit." Hayek is far too sophisticated a scholar to be tarred as arguing that existing institutions are optimal. Nor, while conservatives appropriately place him in their Pantheon, does he deny that conscious public action has played an important role in structuring the institutions we presently have. Rather, his central point is that our present institutional structures must be interpreted as largely the result of a process involving somewhat blind variation and social selection.

However, for reasons he is unable or unwilling to state, Hayek does not lay out exactly "How the West Grew Rich," to borrow a term from Rosenberg and Luther Birdzell (1986). There is little discussion in Hayek about the actual mechanisms that have "selected" the institutions we now have, only some assertions that what we have is the result of social learning. He says virtually nothing about how that occurs, or how it works in the benefit of the society as a whole, as contrasted with favoring individual interests that, when they are aggregated, are destructive of everyone. Yet somehow (he implicitly argues) what we have achieved works pretty well (this is North's point), and in any case messing 
with it in any radical way almost surely will make things worse.

Rosenberg and Birdzell argue a variant of this theme. It is that "the West Grew Rich" because the societies broke loose from the norms and constraints of old institutions, and kept political process from doing too much, and let the "market" work.

But this will not quite do as a coherent theory. The "market" here is not just the market for goods and services or new techniques of production or modes of organizing private production. Rosenberg and Birdzell also are concerned with the institutions of modern science, bodies of law and mechanisms to enforce law and make new law, etc. It probably is useful to posit that these "institutions" "evolved." One can even speak of a "market" for institutional changes. We saw this earlier in the discussion of theories that proposed the law evolved to enhance economic efficiency. But in fact there is no real "market" that sorts out among proposed changes in the law. Rather there is a set of economic and political interests, professional and lay beliefs about what the law should be, and a diverse set of mechanisms, some expressly political and some not, through which these interests and norms influence the evolution of the law. And the same is true for most other things that we lump under the term "economic institutions." We have very little understanding of how this kind of a selection environment works, and how it defines "fitness." (For a similar view see Mary Douglas 1986.) We have no reason to believe that such selection environments are stringent, or stable, much less that they select on "economic efficiency."

And yet, it is arguably the case that the now advanced industrial nations have achieved dramatic economic progress (in most if not all dimensions) over the last century and a half. As argued in an ear- lier section, development of new technology certainly has been the primary force, but institutional structures have evolved to enable new technologies to operate relatively effectively. Indeed, the broad form of the modern corporation with $R \& D$ laboratory, and the modern university, which have become the major sources of technological advance, themselves have coevolved with technology.

It is clear that, somehow, in the now advanced industrial nations, there have been mechanisms that have made the coevolution of technology, industrial organization, and institutions more broadly, move in directions that have led to sustained economic progress. Private actions leading to "self organization" have been part of the story, but collective action has been as well. It is absurd to argue that processes of institutional evolution "optimize"; the very notion of optimization may be incoherent in a setting where the range of possibilities is not well defined, even if the issue of different interests could be resolved in this terminology (as through the set concept of Pareto optimality). However, there seem to be forces that stop or turn around particular directions of institutional evolution that, pursued at great length, would be disastrous. And strong shifts in the needs of large and powerful groups tend to be followed by shifts in the direction of institutional evolution toward ones that better reflect their changed needs. I can conjecture plausible models that yield these results. However, to date they have not been explored analytically with any rigor.

Undoubtedly part of the problem reflects the still primitive state of our ability to work with cultural evolutionary theories. In this particular case I am sure it also stems from an overly broad and vague concept of the variable in question-institutions-which is defined so 
as to cover an extraordinarily diverse set of things. Before we make more headway in understanding how "institutions" evolve we may have to unpack and drastically disaggregate the concept. But our difficulty also may signal the limits of the power of economics or social science theory more generally to comprehend a set of processes as complex as those behind economic growth as we have known it.

\section{Reprise}

This essay has aimed to provide an overview of recent writings by economists, and some other social scientists, who have put forth express theoretical arguments that the variables the authors are examining change through evolutionary processes. I have concentrated on works where empirical subject matter is the focus of attention, and an evolutionary theory is invoked to explain the observed or alleged pattern of change, and largely have neglected works where the formal aspects of an evolutionary theory are central and empirical subject matter brought in mostly as stylized examples. However a unifying characteristic of the writings surveyed here is that the evolutionary theorizing is set out explicitly, as contrasted with coming in mostly as a way of talking about the empirical subject matter.

As I argued in the introduction, the latter long has been common in economics. It is the express evolutionary theorizing that is relatively new.

The theoretical arguments I have surveyed range from quite precise and formal, to storytelling. Virtually all of the them, however, are put forth by their authors to provide a different, and in the author's view a better, theory than one which uses the conventional assumptions of "equilibrium" theorizing.

This of course raises the question of what one might mean by "better." More accurate prediction? "On the button" prediction never has been a hallmark of economic analysis, and it is unlikely that predictions motivated by an evolutionary theoretic framework are systematically better or worse than those motivated by a neoclassical theory. The heart of quantitative prediction making in economics lies in the details of the prediction equations, and these almost always reflect judgment of the particular context as much as formal theory.

Better explanation? If by "better" one means statistical "better fits" in various senses, again the heart of the exercise is in the details of the equations that are fitted, and those details are as much a matter of art as of broad formal theory. Indeed formal general theory usually provides only loose constraints on models designed to fit particular bodies of data.

On the other hand if by "better explanation" one means one that is consistent with informed judgments as to what really is going on, that is exactly the case for evolutionary theory put forth by those that advocate it. In general those informed judgments reflect inferences drawn from a broad and diversified body of data. Thus evolutionary theories of productivity growth at a macroeconomic level feel right to their advocates not simply because they can be tuned to fit those particular data pretty well, but also because the evolutionary explanation is consistent with observed differences in productivity and profit among firms, with the fact that even obviously superior new technology usually diffuses slowly, and like observations, that it takes more strain for neoclassical theory to encompass.

And that, I would argue, is an important part of what the "betterness" criterion ought to be. Does the explanation ring right to those who know the details 
of the field? It would seem that this is the issue Marshall had in mind when he wrote the sentences that began the essay. Mechanical theories did not ring right with him.

But he also raised the issue of complexity. If there is value in formal theorizing in economics it lies in the ability to work through complex causal arguments, but if the complexity is too great one either may lose ability to understand what the theory is doing-what leads to what conclusions-or to check the logic for accuracy, or both. For all the reasons discussed in the introduction, economists now are far better able to deal with analytic complexity in general, and the complexity of evolutionary models in particular, than we were twenty years ago, much less in Marshall's time. There is no doubt, however, that evolutionary theories still tend to be complex.

Thus those who are attracted to developing and employing them to address the phenomena in which they are interested are making an intellectual bet that the price of added complexity is worth paying to buy the better ability to devise and work with a theory that rings right. The bet is that evolutionary theory opens up a productive research program, to use Lakatos' idea, that is foreclosed or more difficult if one stays with mechanical analogies.

The use of formal evolutionary theory in economics is still new, and the proponents of evolutionary theory are struggling with both techniques and standards. It is clear that a number of the evolutionary theories put forth by economists in recent years are difficult to follow in terms of their cause-effect logic, and some may be logically incoherent. Merely adopting evolutionary theoretic language does not automatically lead to a logical model. But a number of the new evolutionary theories do seem coherent, and analytically powerful. The coherence and power of evolutionary theorizing obviously depends on the skill and diligence of the theorist. There would appear to be nothing different here between neoclassical and evolutionary theorizing.

This said, it is clear that one of the appeals of evolutionary theorizing about economic change is that that mode of theorizing does seem better to correspond to the actual complexity of the processes, as these are described by the scholars who have studied them in detail. There is no question that, in taking aboard this complexity, one often ends up with a theory in which precise predictions are impossible or highly dependent on particular contingencies, as is the case if the theory implies multiple or rapidly shifting equilibria, or if under the theory the system is likely to be far away from any equilibrium, except under very special circumstances. Thus an evolutionary theory not only may be more complex than an equilibrium theory. It may be less decisive in its predictions and explanations. To such a complaint, the advocate of an evolutionary theory might reply that the apparent power of the simpler theory in fact is an illusion.

A good case can be made that the topics and sectors where evolutionary theories that have been developed to date are notably weak regarding prediction, and somewhat ad hoc on explanation, are those where standard neoclassical theories have great difficulties also. They are areas where there is no real market, or where market selection is strongly mixed with political or professional influences. The problem in theorizing here clearly lies not in the evolutionary art form, but in the complexity of the subject matter.

Many years ago Veblen (1896) asked, "Why Is Economics Not an Evolutionary Science?" In my view economics would be a stronger field if its theoretical framework were expressly evolutionary. 
Such a framework would help us see and understand better the complexity of the economic reality. That, I think, is its greatest advantage. But it will not make the complexity go away.

\section{REFERENCES}

ABERnathy, William and UTTERBaCK, James M. "A Dynamic Model of Process and Product Innovation," Omega, 1975, 3(6), pp. 639-56.

ALDRICH, HOWARD. Organizations and environments. Englewood Cliffs, NJ: Prentice Hall, 1979.

ANDERSON, PHILIP W.; ARROW, KENNETH J. AND PINES, DAVID, eds. The economy as an evolving complex system. Redwood City, CA: AddisonWesley Pub. Co., 1988.

AOKI, MASAHIKO. "Toward a Model of the Japanese Firm," J. Econ. Lit., Mar. 1990, 28, pp. $1-27$.

ARTHUR, W. BRIAN. "Self-reinforcing Mechanisms in Economics," in PHILIP W. ANDERSON, KENNETH J. ARROW, AND DAVID PINES, eds. 1988a, pp. 9-31.

_- "Competing Technologies: An Overview," in GIOVANNI DOSI ET AL., eds. 1988b, pp. 590-607.

- Competing Technologies, Increasing Returns, and Lock-In by Historical Events," Econ. J., Aug. 1989, 99(394), pp. 116-31.

BASALLA, GEORGE. The evolution of technology. Cambridge: Cambridge U. Press, 1988.

BAUM, JOEL A. C. AND Singh, JitendRA V. Evolutionary dynamics of organizations. New York: Oxford U. Press, 1994.

Bijker, Wiebe E.; Hughes, Thomas P. AND PINCH, TREVOR J. The social construction of technological systems. Cambridge, MA: MIT Press, 1987.

Boyd, Robert and Richerson, Peter J. Culture and the evolutionary process. Chicago: $\mathrm{U}$. of Chicago Press, 1985.

Burgelman, Robert A. "Fading Memories: A Process Study of Strategic Business Exit in Dynamic Environments." Stanford Business School xerox, June 1993.

CAMPBELL, DONALD. "Blind Variation and Selective Retention in Creative Thought as in Other Knowledge Processes," Psychological Rev., 1960, 67, pp. 380-400.

. "Evolutionary Epistemology," in The philosophy of Karl Popper. Ed.: PAUL A. SCHILPP. LA SALLE, IL: Open Court, 1974, pp. 413-63.

Casella, Alessandra and Frey, BRUno S. "Federalism and Clubs: Towards an Economic Theory of Overlapping Political Jurisdictions," Europ. Econ. Rev., Apr. 1992, 36(2-3), pp. 63946.

CAVAlli-SForza, LUigi L. AND FELdMaN, MARCUS W. Cultural transmission and evolution: A quantitative approach. Princeton: Princeton U. Press, 1981.
CHANDLER, ALFRED D. Strategy and structure: Chapters in the history of industrial enterprise. Cambridge: Harvard U. Press, 1962.

- Scale and scope: The dynamics of industrial capitalism. Cambridge: Harvard U. Press, 1990.

ChIAROMONTE, FRANCESCA AND DOSI, GIOVANNI. "Heterogeneity, Competition, and Macroeconomic Dynamics," Structural Change and Economic Dynamics, 1993, 4, pp. 39-63.

CHRISTENSEN, CLAYTON AND ROSENBLOOM RICHARD. "Explaining the Attacker's Advantage: Technological Paradigms, Organizational Dynamics, and the Value Network," Research Policy, forthcoming.

Clark, Norman and JUma, Calestous. Long run economics: An evolutionary approach to economic growth. London: Pinter Pub., 1987.

Cohen, Wesley M. And Levinthal, Daniel A. "Innovation and Learning: The Two Faces of $R$ \& D," Econ. J., Sept. 1989, 99(397), pp. 569-96.

CONLISK, JOHN. "An Aggregate Model of Technical Change," Quart. J. Econ., Nov. 1989, 104(4), pp. 787-821.

COOL, KAREl AND SCHENDEl, DAN. "Performance Differences Among Strategic Group Members," Strategic Manage. J., 1988, 9(3), Pp. 20723.

CoOter, Robert D. AND RUBinfeld, Daniel L. "Economic Analysis of Legal Disputes and Their Resolution," J. Econ. Lit., Sept. 1989, 27(3), pp. 1067-17.

DAVID, PAUL A. Technical choice, innovation and economic growth. Cambridge: Cambridge U. Press, 1975 .

- "Clio and the Economics of QWERTY," Amer. Econ. Rev., May 1985, 75(2), pp. 332-37.

- "Heroes Herds and Hysteresis in Technological History," Industrial and Corporate Change, 1992, 1(1), pp. 129-79.

DaVis, LANCE E. AND NORTH, DOUglass C. Institutional change and American economic growth. Cambridge: Cambridge U. Press, 1971.

DAY, RICHARD H. AND Eliasson, GUNNAR. The dynamics of market economies. Amsterdam: North Holland, 1986.

DE BRESSON, Chris. "The Evolutionary Paradigm and the Economics of Technological Change," J. Econ. Issues, June 1987, 21 (2), pp. $751-62$.

DEMSETZ, HaROLD. "Toward a Theory of Property Rights," Amer. Econ. Rev. , May 1967, 57(2), pp. 347-59.

Dosi, Giovanni. "Technological Paradigms and Technological Trajectories: A Suggested Interpretation of the Determinants and Directions of Technical Change," Research Policy, 1982, 11(3), pp. 147-62.

. "Sources, Procedures, and Microeconomic Effects of Innovation," J. Econ. Lit., Sept. 1988, 26(3), pp. 1120-71.

DOSI, GIOVANNI ET AL., eds. Technical change and economic theory. London: Pinter Pub., 1988. 
Dosi, Grovanni; TeEce, David and Winter, SIDNEY. "Towards a Theory of Corporate Change: Preliminary Remarks," in Technology and enterprise in a historical perspective. Eds.: GIOVANNI DOSI, RENATO GIANNETTI, AND PIER ANGelo TONINELli. Oxford: Clarendon Press, 1992, pp. 185-211.

DOUGLAS, MARY. How institutions think. Syracuse: Syracuse U. Press, 1986.

Durham, William H. Coevolution: Genes, culture, and human diversity. Stanford: Stanford U. Press, 1991.

EgGertsson, Thrainn. Economic behavior and institutions. Cambridge: Cambridge U. Press, 1990.

Elliot, Donald. "The Evolutionary Tradition in Jurisprudence," Columbia Law Rev., Jan. 1985, 85, pp. 38-94

FLIGSTEIN, NEIL. The transformation of corporate control. Cambridge: Harvard U. Press, 1990.

FONTANA, W. AND BUSS, LEO W. "What Would Be Preserved if the Tape Were Played Twice." Santa $\mathrm{Fe}, \mathrm{NM}$ : Santa Fe Institute mimeo, 1992.

FREEMAN, CHRISTOPHER. The economics of industrial innovation. London: Penguin, 1974. "The Nature of Innovation and the Evolution of the Productive System," in Technology and productivity. Paris: OECD, 1991, pp. 30314.

FRIEDMAN, DANIEL. "Evolutionary Games in Economics," Econometrica, May 1991, 59(2), pp. $637-66$.

FrIEDMAN, MILTON. Essays in positive economics. Chicago: U. of Chicago Press, 1953.

GILSON, Ronald J. AND RoE, MaRK J. "Understanding the Japanese Keiretsu: Overlaps Between Corporate Governance and Industrial Organization," Yale Law J., Jan. 1993, 102(4), pp. 871-906.

Gort, Michael and Klepper, Steven. "Time Paths in the Diffusion of Product Innovations," Econ. J., Sept. 1982, 92(367), pp. 630-53.

GOULD, STEPHEN J. The panda's thumb: More reflections on natural history. New York, Norton, 1980.

1-The flamingo's smile: Reflections in natural history. New York: Norton, 1985.

Granovetter, Mark. "Economic Action and Social Structure," Amer. J. Sociology, Nov. 1985, 91(3), pp. 481-510.

Hannan, Michael T. and Carroll, Glenn R. Dynamics of organizational populations. New York: Oxford U. Press, 1992.

Hannan, Michael J. And Freeman, John. Organizational ecology. Cambridge: Harvard U. Press, 1989.

HARRISON, BENNETT. "Industrial Districts: Old Wine in New Bottles," Reg. Stud., 1992, 26(5), pp. 469-83.

HAYEK, FRIEDRICH. The fatal conceit: The errors of socialism. Chicago: U. of Chicago Press, 1988 .

HENDERSON, REBECCA. "Underinvestment and
Incompetence as Responses to Radical Innovation: Evidence from the Photolithographic Alignment Equipment Industry," Rand J. Econ., Summer 1993, 24(2), pp. 248-70.

HENDERSON, REBECCA AND ClARK, Kim. “Architectural Innovation: The Reconfiguration of Existing Product Technologies and the Failure of Established Firms," Admin. Sci. Quart., 1990, 35(1), pp. 9-30.

HIRSHLEIFER, JACK, AND MARTINEZ-COLL, JUAN CARLOS. "What Strategies Can Support the Evolutionary Emergence of Cooperation," J. Conflict Resolution, June 1988, 32(2), pp. 36798.

HODGSON, GEOFFREY M. Economics and institutions. Cambridge: Polity Press, 1988.

tra Pangloss," J. Econ. Issues, June 1991, 25 (2), pp. 519-33.

Pp. "Thorstein Veblen and Joseph Schumpeter on Evolutionary Economics." ZIF Research Group, Biological Foundations of Human Culture. U. of Bielefeld, Germany, 1991/92.

- Economics and evolution: Bringing life back into economics. Cambridge: Polity Press, 1993.

HOLLAND, JOHN H. ET AL. Induction: Processes of inference, learning, and discovery. Cambridge: MIT Press, 1986.

HUGHES, THOMAS P. Networks of power: Electrification in Western society, 1880-1930.. Baltimore: Johns Hopkins U. Press, 1983.

HULL, DAVID. Science as a process. Chicago: U. of Chicago Press, 1988

IWAI, KATSUHITO. "Schumpeterian Dynamics Part I," J. Econ. Behav. Organ., June 1984, 5(2), pp. $159-90$.

15. "Schumpeterian Dynamics Part II," J. Econ. Behav. Organ., Sept.-Dec. 1984, 5(3-4), pp. 321-51.

Kandori, Michihiro; Mailath, George J AND ROB, RAFAel. "Learning, Mutation, and Long Run Equilibria in Games," Econometrica, Jan. 1993, 61(1), pp. 29-56.

KaTz, Michael aND Shapiro, Carl. "Systems Competition and Network Effects," J. Econ. Perspectives, 1994, 8, pp. 93-116.

KLePPER, STEven. "Entry, Exit, Growth, and Innovation Over the Product Cycle." CarnegieMellon U., unpublished manuscript, 1993.

KLePPER, STEVEN AND GRADdy, Elizabeth "The Evolution of New Industries and the Determinants of Market Structure," Rand J. Econ., Spring 1990, 21(1), pp. 27-44.

KUHN, THOMAS S. The structure of scientific revolutions. Chicago: U. of Chicago Press, 1970.

LAKATOS, IMRE. "Falsification and the Methodology of Scientific Research Programmes," in Criticism and the growth of knowledge. Eds.: IMRE LAKATOS AND ALAN MUSGRAVE. New York: Cambridge U. Press, 1970, pp. 91-196.

LANDES, William M. AND POSNeR, Richard A. The economic structure of tort law. Cambridge: Harvard U. Press, 1987. 
LANE, David. "Artificial Worlds and Economics," J. Evolutionary Econ., 1993, 3 (11), pp. 89108.

LANGLOIS, RICHARD N., ED. Economics as a process: Essays in the new Institutional Economics. New York: Cambridge U. Press, 1986.

- "Transaction Cost Economics in Real Time," Industrial and Corporate Change, 1992, 1 (1), pp. 99-127.

LANGlois, Richard and Everett, MichaEl. "What is Evolutionary Economics." Storrs, CT: U. of Connecticut, unpub. ms., 1992.

LATOUR, BRUNO. Science in action. London: Milton Keynes Press, 1986.

LAZONICK, WILLIAM. Competitive advantage on the shop floor. Cambridge: Harvard U. Press, 1990.

LEWONTIN, RICHARD C. The genetic basis of evolutionary change. New York: Columbia U. Press, 1974.

LumSDEn, Charles J. AND Wilson, EdWard $\mathrm{O}$. Genes, mind, and culture. Cambridge: Harvard U. Press, 1981.

MAGNUSSON, LARS, ed. Evolutionary and neoSchumpeterian approaches to economics. London: Kluwer Academic Pub., 1994.

Malerba, Franco and Orsenigo, Luigi. "Industry Evolution and Artificial Worlds." Paper presented for the Workshop on Artificial World Models. Santa Fe Institute. Santa Fe, NM, Nov. 11-14 1993.

- "The Dynamics and Evolution of Industries." Ms. Dept. of Economics, Bocconi U., 1994.

March, James G. and Simon, Herbert A. Organizations. New York: Wiley, 1958.

Marshall, Alfred. Principles of economics. 8th ed. London: Macmillan, 1948.

MAYNARD SMITH, J. Evolution and the theory of games. Cambridge: Cambridge U. Press, 1982.

MAYR, ERNST. Toward a new philosophy of biology. Cambridge: Harvard U. Press, 1988.

MCGUiRe, Patrick; GranovetTer, Mark and SCHWARTZ, MICHAEL. "Thomas Edison and the Social Construction of the Early Electrical Industry in the United States," in Explorations in economic sociology. Ed.: RICHARD SWEDBERG. New York: Russell Sage, 1993.

Metcalfe, Stanley. "The Diffusion of Innovation: An Interpretative Survey," in Giovanni Dosi et al. eds. 1988, pp. 560-89.

."Variety, Structure, and Change: An Evolutionary Perspective on the Competitive Process," Revue D'Economie Industrielle, 1992, (59), pp. 46-61.

Metcalfe, Stanley and Gibbons, Michael. "Technology, Variety and Organization," in Research on technological innovations, management and policy. Eds.: RICHARD S. ROSEN. BLOOM AND ROBERT A. BURGELMAN. JAI Press, 1989, 4, pp. 153-93.

MILgROM, PAUl AND ROBERTS, JohN, "The Economics of Modern Manufacturing," Amer. Econ. Rev., June 1990, 80(3), pp. 511-28.
MOKYR, JOEL. The lever of riches. New Yord: Oxford U. Press, 1990.

MUELleR, DENNIS. Public choice II. Cambridge: Cambridge U. Press, 1989.

MUEller, DENnis AND TILTON, JOHn. “Research and Development Costs as Barriers to Entry," Can. J. Econ., Nov. 1969, 2(4), pp. 57079.

NACHBAR, JOHN. "Evolution in the Finitely Repeated Prisoner's Dilemma," J. Econ. Behav. Organ., Dec. 1992, 19(3), pp. 307-26.

NELSON, RICHARD R. AND ROSENBERG, NATHAN. "Technical Innovation and National Systems," in National innovation systems: A comparative study. Ed.: RICHARD R. NELSON. New York: Oxford U. Press, 1993, pp.

NELSON, RICHARD R. AND WINTER, SIDNEY. "Neoclassical vs. Evolutionary Theories of Economic Growth: Critique and Prospectus," Econ. J., Dec. 1974, 84(336), pp. 886-905.

- "In Search of a Useful Theory of Innovation," Research Policy, 1977, 6(1), pp. 3676.

- An evolutionary theory of economic change. Cambridge: Harvard U. Press, 1982.

NORTH, DOUGLASS C. Institutions, institutional change, and economic performance. Cambridge: Cambridge U. Press, 1990.

PENROSE, EDITH. "Biological Analogies in the Theory of the Firm," Amer. Econ. Rev., Dec. 1952, 42(5), pp. 804-19.

Perez, Carlotta. "Structural Change and the Assimilation of New Technology in the Economic and Social System," Futures, 1981.

Perrow, Charles. Complex organizations: A critical essay. 3rd ed. Glenview, IL: Scott Foresman, 1986.

PETROSKI, HENRY. The evolution of useful things. New York: Alfred Knopf, 1993.

Piore, MichaEl J. AND SABEl, Charles F. The second industrial divide: Possibilities for prosperity. New York: Basic Books, 1984.

PlotKIN, HENRY C. Learning, development, and culture: Essays in evolutionary epistemology. New York: John Wiley, 1982.

POPPER, KARL R. Conjectures and refutations: The growth of scientific knowledge. New York: Harper Torchbooks, 1968.

Powell, Walter W. and Dimaggio, Paul J., EDS. The New institutionalism in organizational analysis. Chicago: U. of Chicago Press, 1991.

PRIgOGINe, ILYA AND STENGERS, ISABELle. Order out of chaos. London: Fontana, 1984.

Romanelli, Elaine. "The Evolution of New Organizational Forms," Annual Review of Sociology, 1991, 17, pp. 79-103.

ROMER, PAUL. "Increasing Returns and New Developments in the Theory of Growth, " in Equilibrium theory and applications. Eds.: WILLIAM BARNETT ET AL. Cambridge: Cambridge U. Press, 1991, pp. 83-110.

Rosenberg, NAthan. Perspectives on technology. Cambridge: Cambridge U. Press, 1976. 
. Inside the black box: Technology and economics. Cambridge: Cambridge U. Press, 1982.

ROSENBERG, NATHAN AND BIRDZELL, LUTHER E. How the West grew rich. New York: Basic Books, 1986.

ROSENKOPF, LORI AND TUSHMAN, MICHAEL "The Coevolution of Technology and Organization," in JOEL A. C. BAUM AND JITENDRA V. SINGH 1994.

RUBEN, P. AND BAILey, M. "A Positive Theory of Legal Change." Dept. of Economics, Emory U., Atlanta, GA. Unpub. ms., 1992.

RUMELT, RICHARD P. "How Much Does Industry Matter?" Strategic Management J., 1991, 12(3), pp. 167-85.

Sabel, Charles and Zeitlin, Jonathan. "Stories, Strategies, Structures: Rethinking Historical Alternatives to Mass Production." ms., 1993.

SAHAL, DEVENDRA. Patterns of technological innovation. Reading, MA: Addison-Wesley, 1981.

Saviotti, Paolo and Metcalfe, J. Stanley, EDS. Evolutionary theories of economic and technological change. Reading, MA: Harwood Academic Pub., 1991.

SchofmaKer, PAUL J. "The Quest for Optimality: A Positive Heuristic of Science?" Behavioral and Brain Sciences, June 1991, 14(2), pp. 20545.

SCHOTTER, ANDREW. The economic theory of social institutions. Cambridge: Cambridge $U$. Press, 1981

- "The Evolution of Rules," in RICHARD LANGLOIS, ed. 1986, pp. 117-33.

SCOTT, W. RICHARD. Organizations: Rational, natural, and open systems. 3rd ed. Englewood Cliffs, NJ: Prentice Hall, 1992.

SCHUMPETER, JOSEPH A. Capitalism, socialism, and democracy. 5th ed. London: George Allen \& Unwin, [1942] 1976.

SilverberG, Gerald. "Technical Progress, Capital Accumulation, and Effective Demand: A Self Organizing Model," in Economic cvolution and structural adjustment. Eds.: DAVID BATTEN, JOHN CASTI, AND BORJE JOHNSEN. Berlin: Springer-Verlag, 1987, pp. 116-44.

SilverberG, Gerald; Dosi, Giovanni and ORSENIGO, LUIGI. "Innovation, Diversity and Diffusion: A Self Organizing Model," Econ. J., Dec. 1988, 98(393), pp. 1032-54.

SIMON, HERBERT. Administrative behavior. New York: Free Press, 1947.

Simon, Herbert and Bonini, Charles. "The Size Distribution of Business Firms," Amer. Econ. Rev., Sept. 1958, 48, pp. 607-17.

SMELSER, NEIL AND SWEDBERG, RICHARD, EDS. Handbook of economic sociology. Princeton: Princeton U. Press, 1994.

SOBER, ELLIOTT, ED. Conceptual issues in evolutionary biology. Cambridge: MIT Press, 1984.

SOETE, LUC AND TURNER, ROY. "Technology Diffusion and the Rate of Technical
Change," Econ. J., Sept. 1984, 94(375), pp. 612-23.

Solow, ROBERT. "A Contribution to the Theory of Economic Growth," Quart. J. Econ., Feb. 1956,70 , pp. 65-94.

SPENCER, HERBERT. The factors of organic evolution. London: Williams \& Norgate, 1887.

SUGDEN, Robert. "Spontaneous Order," J. Econ. Perspectives, Fall 1989, 3(4), pp. 85-97.

Tushman, Michael L. AND ANDerson, Philip. "Technological Discontinuities and Organizational Environments," Administrative Sciences Quart., 1986, 31, pp. 439-65.

TUSHMAN, MICHAEL L. AND ROMANELl, Elaine. "Organizational Evolution: A Metamorphis Model of Convergence and Reorientation," in Research in organizational behavior. Eds.: B. M. STAW AND LARRY L. CUMMINGS. Greenwich, CT: JAI Press, 1985, 7, pp. 171222.

TUSHMAN, MICHAEL AND ROSENKOPF, LORI "Organizational Determinants of Technological Change: Toward a Sociology of Technological Evolution," Research in organizational behavtor, 1992, 14, pp. 311-47.

UTTERBACK, JAMES. Mastering the dynamics of innovation. Boston: Harvard Business School Press, 1994.

UTTERBACK, JAMES AND SUAREZ, FERnANDo. "Innovation, Competition, and Market Structure," Research Policy, 1993, 22(1), pp. 1-21.

VEBLEN, THORSTEIN. "Why Is Economics Not an Evolutionary Science?," Quart. J. Econ., 1898 12, pp. 373-97. Imperial Germany and the industrial revolution. New York: Macmillan, 1915.

VERSPAGEN, BART. "Endogenous Innovation in Neo-classical Growth Models: A Survey," J. Macroeconomics, Fall 1992, 14, pp. 63162.

VINCENTI, WALTER. What engineers know and how they know it? Baltimore: Johns Hopkins Press, 1990.

"The Retractable Airplane Landing Gear and the Northrup Anomaly: Variation-Selection and the Shaping of Technology," Technology and culture, 1994, 35, pp. 1-33.

WILliamsON, OliVER E. The economic institutions of capitalism. New York: Free Press, 1985.

WINTER, SIDNEY G. "Economic 'Natural Selection' and the Theory of the Firm," Yale Econ. Essays, 1964, 4(1), pp. 225-72.

"Schumpeterian Competition in Alternative Technological Regimes," J. Econ. Behav. Organ., Sept.-Dec. 1984, 5(3-4), pp. 287320.

"The Research Program of the Behavioral Theory of the Firm: Orthodox Critique and Evolutionary Perspective, ${ }^{n}$ in Handbook of behavioral economics. Volume A. Eds.: BENJAMIN Gilad and STANLEY KaISH. Greenwich, CT: JAI Press, 1986, pp. 242-45.

. "Comments [Rationality of Self and Others in an Economic System] [Adoptive Behavior 
and Economic Theory]," in J. Bus., Part 2. Oct. 1986, 59(4), pp. S427-34.

WITT, ULRICH. "The Evolution of Economic Institutions as a Propagation Process," Public Choice, Aug. 1989, 62(2), pp. 155-72. ed. Evolutionary economics. London: Edward Elgar, 1993.

YounG, H. PEYTON. "The Evolution of Conventions," Econometrica, Jan. 1993, 61(1), pp. 5784. 

